Historic, Archive Document

Do not assume content reflects current scientific knowledge, policies, or practices. 



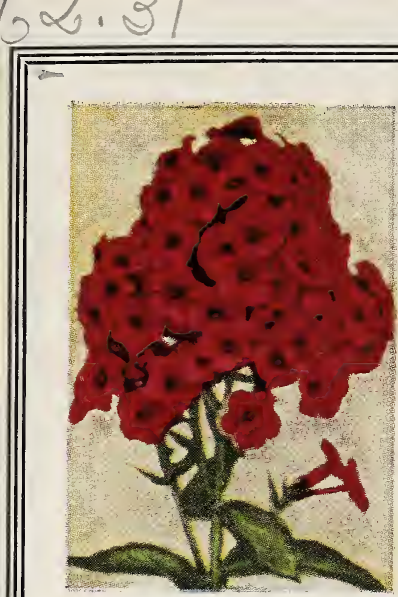

HARDY PHLOX

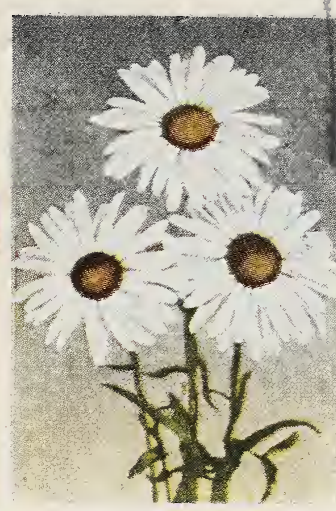

SHASTA DAISY

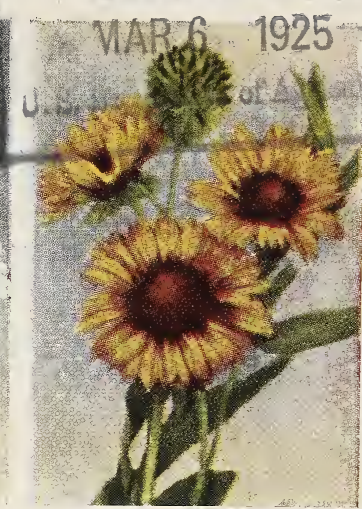

GAILLARDIA

\section{Seeds $\cdot$ Bulbs $\cdot$ Plants 1925}

\section{Powell Seed Company INCORPORATED \\ 118 South Second Street Louisville, Kentucky}

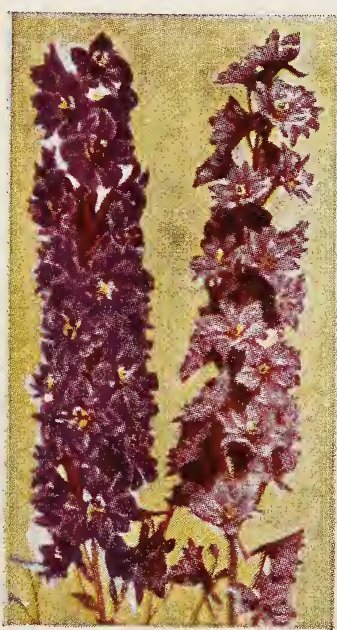

DELPHINIUM
Hardy Perennial Flowers Sill flower in abun- $_{\text {Once }}$ dance from year to year. One each of the plants illustrated $\$ 1.10$ postpaid; three of each variety [18 plants] $\$ 3.00$ postpaid
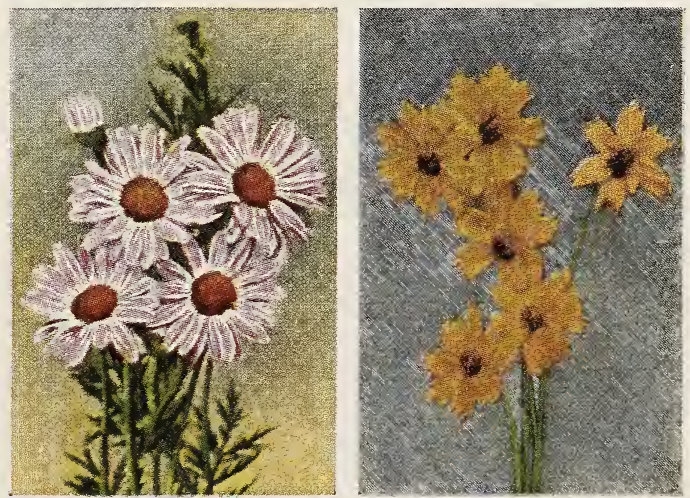

PYRETHRUM 


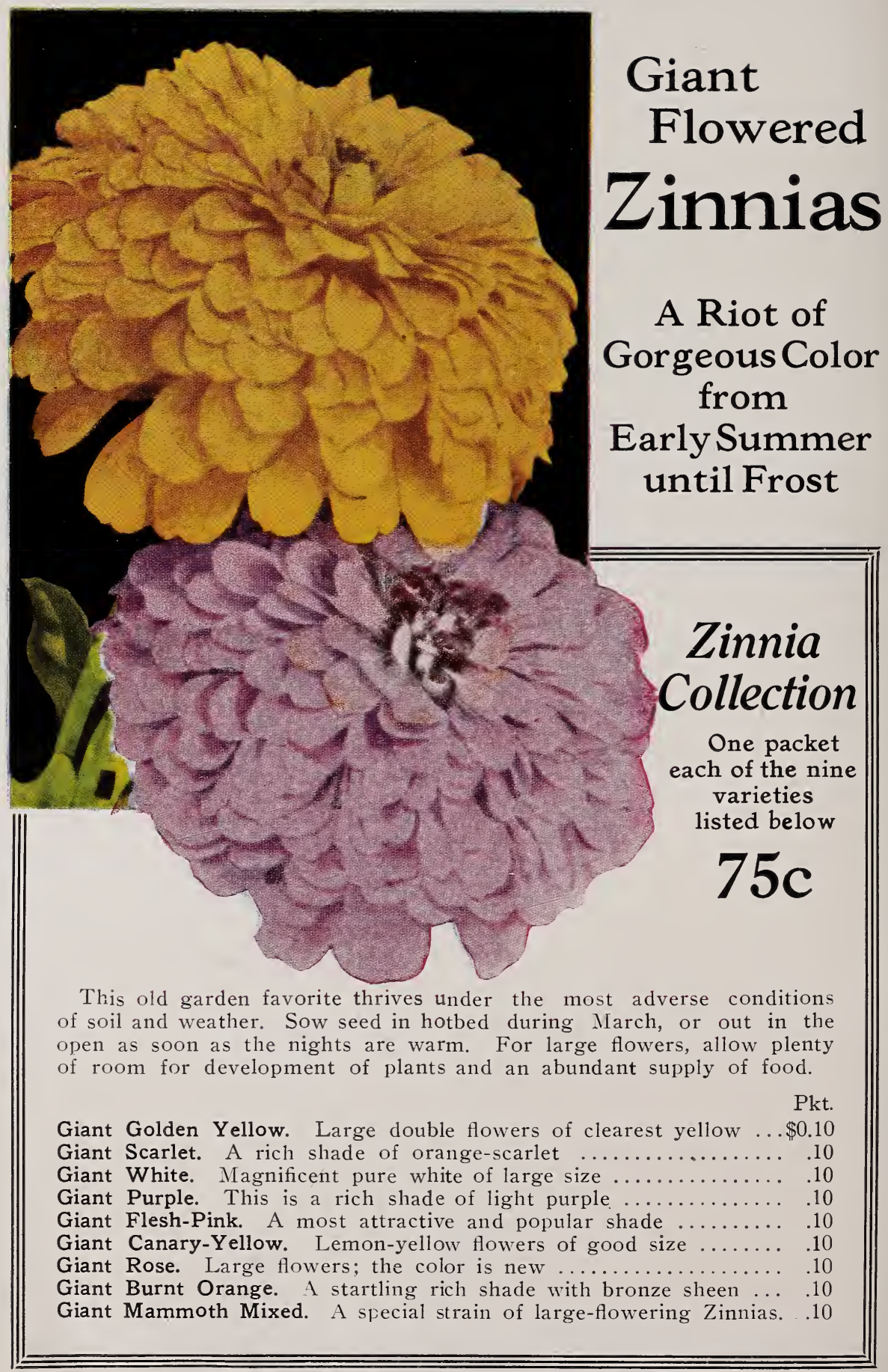




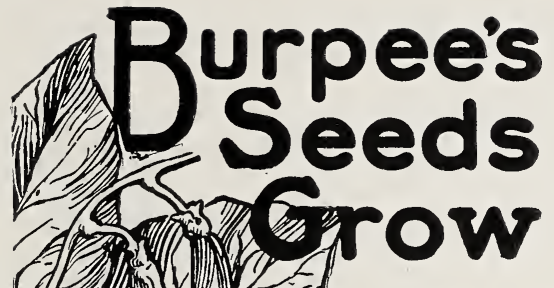

PARCEL POST. We prepay the postage on all seed in packets, ounces, half pounds and pounds, also on bulbs and plants when ordered by the dozen at catalog prices.

CITY DELIVERY. We deliver heavy parcels of seed and fertilizer to any part of the city. F'reight shipments will be delivered to depots without charge.

MAII ORDERS should have sender's name and address plainly written and should be accompanied by explicit shipping instructions.

FIELD SEED. Orders will be filled at prices prevailing at time of shipment. Prices quoted will be subject to change without notice.

NON-WARRANTY. There are so many elements entering into the success or failure of crops, such as soil, weather and cultural methods that, in common with all reputable seed houses, we give no warranty, express or implied, as to description, purity, productiveness, or any other matter of any seeds, bulbs or plants we send out, and we will not be responsible in any way for the crop.

If on receipt of any garden or flower seeds ordered from this catalog, you are not pleased with the quality, they are to be immediately returned and we will cheerfully refund the purchase price.

\section{CONTENTS}

The following order has been observed in the preparation of this catalog:

Vegetable Seeds
Field Seeds
Flower Seeds
Hardy Perennial Plants
Bulbs
Books
Garden Accessories

\section{Fiertilizers}

Insecticides

Sprayers and Dusters

Poultry Supplies

Poultry Remedies

Lawn Grass

Complete index on page 44 . 


\section{ARTICHOKE}

ARTICHOKE GREEN GLOBE is a perennial cultivated for its flower heads, which are cooked like Asparagus. Packet, 15c.

\section{ASPARAGUS}

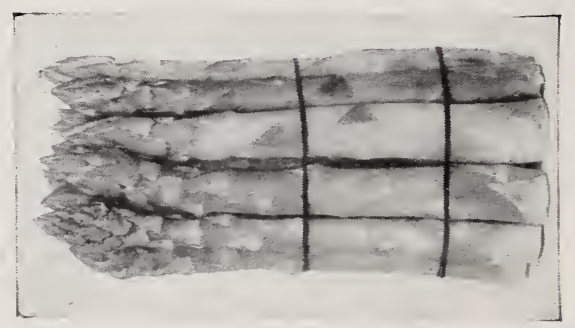

ASPARAGUS-Plant in well drained soil with Southern exposure. Ask for our free cultural directions. Barr's Mammoth, two-year-old roots, 50 for $\$ 1.20 ; 100$ for $\$ 2.15$, postpaid.

\section{BUSH BEANS}
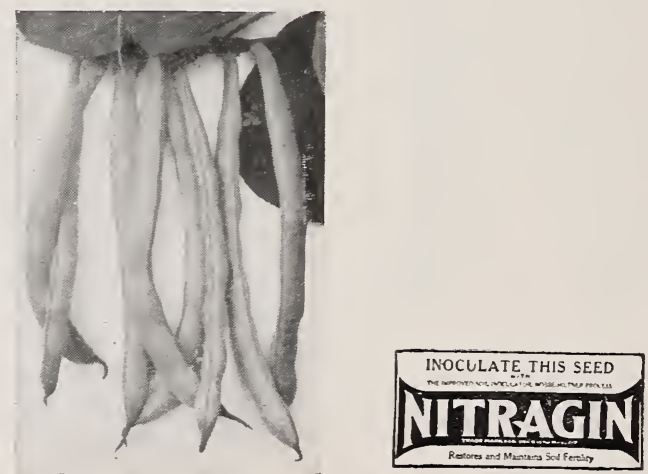

BURPEE'S STRINGLESS GREEN-POD-The finest bean. The pods are tender, brittle and juicy. Seeds dark brown. Can be planted from May till August. Pkt., $10 \mathrm{c} ; \mathrm{I} / 2 \mathrm{lb} ., 20 \mathrm{c} ; 1 \mathrm{~b} ., 40 \mathrm{c}$.

FULI MEASURE full, round pods measuring 6 inches in length. Moder' ately early. Pkt., $10 \mathrm{c}$; $1 / 2$ lb., $20 \mathrm{c}$; lb., $40 \mathrm{c}$.

BOUNTIFUI is recommended for early planting as the stringless, flat, green pods are produced early in the season. Pkt., $10 \mathrm{c} ; 1 / 2 \mathrm{lb} ., 20 \mathrm{c}$; lb., $40 \mathrm{c}$.

EXTRA EARLY RED VALENTINE-A hardy and early-maturing sort, bearing deeply saddle-backed pods measuring 4 inches long. Good for canning and market garden. Pkt., $10 \mathrm{c} ; 1 / 2 \mathrm{lb} ., 20 \mathrm{c} ; 1 \mathrm{~b} ., 40 \mathrm{c}$.

BLACK VALENTINE-Matures early with long, round, straight pods. Pkt., 10c; $1 / 2$ lb., $20 \mathrm{c} ; 1 \mathrm{~b} ., 40 \mathrm{c}$. 
TFNNESSEE GREEN-POD-This is a tremendous eropper, with straight, long, flat pods. Stringy and otherwise not desirable for home use. Pkt., 10c; 1/2 lb., 20c; lb., 40c.

FORDHOOK FAVORITE-A white seeded, high quality bean bearing brittle, fleshy pods, continuously through the season if kept picked. Is entirely stringless. Pkt., $10 \mathrm{c} ; 1 / 2 \mathrm{lb} ., 25 \mathrm{c} ; 1 \mathrm{~b} ., 45 \mathrm{c}$.

GIANT STRINGLESS GREEN-POD-A fine mid-season variety for either home or market garden. Pods are meaty, brittle and stringless. Pkt., $10 \mathrm{e} ; 1 / 2 \mathrm{lb} ., 20 \mathrm{c} ; 1 \mathrm{~b} ., 40 \mathrm{c}$.

\section{WAX POD BUSH BEANS}

BURPEE'S BRITTLE WAX-An early and heavy producer of very fine quality. Pkt., $15 \mathrm{c} ; 1 / 2 \mathrm{lb} ., 30 \mathrm{c} ; \mathrm{lb} ., 55 \mathrm{c}$.

PENCIL-POD BLACK WAX-Stringless yellow pods. Early and of fine flavor. Pkt., $10 \mathrm{c} ; 1 / 2$ lb., $20 \mathrm{c} ; 1 \mathrm{~b} ., 40 \mathrm{c}$.

BURPEE'S KIDNEY WAX-Long, broad pods, fleshy and entirely stringless. Pkt., $10 \mathrm{c} ; 1 / 2$ lb., $20 \mathrm{c} ; 1 \mathrm{~b} ., 40 \mathrm{c}$.

\section{SHELL BEANS}

IMPROVED WHITE NAVY-Pkt., 10c; 1/2 lb., 20c; lb., $35 \mathrm{c}$.

DWARF HORTICUITURAI-Fine for Winter shell beans, but may be used both as snap and green-shell beans. A great favorite with Italians. Pkt., $10 \mathrm{c} ; 1 \mathrm{~b} ., 40 \mathrm{c}$.

RED KIDNEY-Pkt., $10 \mathrm{c} ; 1 / 2 \mathrm{lb} ., 20 \mathrm{c} ; 1 \mathrm{~b} ., 40 \mathrm{c}$.

\section{POLE BEANS}

KENTUCKY WONDER OR OLD HOMESTEAD-The most popular climb ing or corn-hill bean. Very productive and of good flavor. Pkt., $10 \mathrm{c} ; 1 / 2$ lb., $20 \mathrm{c}$; lb., $40 \mathrm{c}$.

BURGER'S STRINGLESS GREEN-POD-This is a White-Seeded Kentucky Wonder. Pkt., $10 \mathrm{c} ; 1 / 2$ lb., $20 \mathrm{c} ; 1 \mathrm{~b} ., 40 \mathrm{c}$.

WHITE CREASEBACK-Pkt., $10 \mathrm{c} ; 1 / 2 \mathrm{lb} ., 20 \mathrm{c} ; 1 \mathrm{~b} ., 40 \mathrm{c}$.

IAZY WIFE'S-A late, productive, white-seeded sort. Pkt., 10c; 1/2 lb., $20 \mathrm{c} ; 1 \mathrm{~b}, \mathrm{c} 40 \mathrm{c}$.

HORTICUITURAI-When young the pods may be used as snap-shorts. The large, red-speckeled beans are grown for Winter use. Pkt., 10c; $1 / 2$ lb., $20 \mathrm{c}$; lb., $40 \mathrm{c}$.

KENTUCKY WONDER WAX-Pkt., 10c; 1/2 lb., 30c; lb., 50c.

RED SPECKLED CUT-SHORT OR CORN HILI-A well known variety for planting in eorn hills. Fine grained pods of good quality. Stringy. Pkt., 10c; lb., $40 \mathrm{c}$.

\section{BUSH LIMA BEANS}

BURPEE'S BUSH IIMA-Very productive, mid-season variety Pkt., 10c; $1 / 2$ lb., $20 \mathrm{c} ; \mathrm{lb} ., 40 \mathrm{c}$.

BURPEE'S IMPROVED BUSH-5 to 6-inch pods of large, luseious beans, usually borne in clusters. A splendid producer for home or market garden. Pkt., $10 \mathrm{c} ; 1 / 2 \mathrm{lb} ., 25 \mathrm{c} ; 1 \mathrm{~b} ., 45 \mathrm{c}$.

FORDHOOK-Of erect bush growth. The pods measure 4 to 5 inches in length and are often $3 / 4$ inch in thickness. The excellent thick beans are of the Potato-Lima type. Pkt., $15 \mathrm{c} ; 1 / 2 \mathrm{lb} ., 25 \mathrm{c} ; \mathrm{lb} ., 50 \mathrm{c}$.

WOOD'S PROLIFIC OR IMPROVED HENDERSON-Tremendous bearer of well filled pods of small, deliciously flavored beans. Early. Pkt., $10 \mathrm{e} ; 1 \mathrm{~b} ., 40 \mathrm{e}$. 


\section{POLE LIMA OR BUTTER BEANS}

CHALLENGER OR CARPENTERIA (Potato Lima) Late, productive sort. Pods contain 3 to 5 very thick beans. Pkt., $10 \mathrm{c} ; 1 / 2$ lib., $25 \mathrm{c} ; 1 \mathrm{~b} ., 45 \mathrm{c}$.

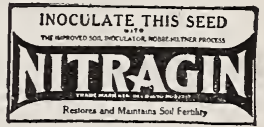

GIANT PODDED POLE LIMA (Crop Failed)

KING OF THE GARDEN-Strong grower. Large pods, well filled. Good for home or market. Pkt., $10 \mathrm{c}$; lb., $40 \mathrm{c}$.

EARLY LEVIATHAN-Early, hardy and prolific. Pods are 5 to 6 inches long. Sure cropper. Pkt., $15 \mathrm{c} ; \mathrm{lb}, 50 \mathrm{c}$.

SUNNYBROOK POLE IIMA-Extremely early and very prolific. Bears throughout season. Quality finest. Pkt., $25 \mathrm{c}$; lb., $75 \mathrm{c}$.

CAROLINA OR SIEVA-This is the famous butter bean of the South. Very early and vigorous grower, producing small beans of finest quality. Pkt., 10c; lb., $40 \mathrm{c}$.

Can be stored for Winter

in a cellar.

Cover with moist earth.

\section{BEETS}

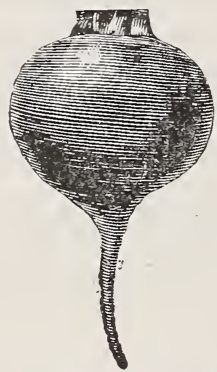

For successsion sow

once a month up

to July 1 st.

ECLIPSE-An early variety with small tops and medium sized, bright red flesh, zoned pinkish white. Pkt., $10 \mathrm{c}$; oz., $15 \mathrm{c} ; 1 / 4 \mathrm{lb} ., 30 \mathrm{c} ; 1 \mathrm{~b} ., 85 \mathrm{c}$.

BURPEE'S EXTRA EARLY-Flesh in alternate ring's of light and dark pink, slightly flattened smooth roots. Sweet and tender. Pkt.. 10c; oz., $25 \mathrm{c} ; 1 / 4 \mathrm{lb} ., 50 \mathrm{c}$.

DETROIT DARK RED-Smooth, globular roots with small tops. A good canner and a splendid variety for home or market. Pkt., 10c; oz., $15 \mathrm{c} ; 1 / 4 \mathrm{lb} ., 30 \mathrm{c} ; 1 \mathrm{~b} ., 90 \mathrm{c}$.

CROSBY'S EGYPTIAN-A leading variety for early market on account of its attractive shape and good quality. Pkt., $10 \mathrm{c} ; 0 \mathrm{z}, 15 \mathrm{c} ; 1 / 4 \mathrm{lb}$., $40 \mathrm{c} ; 1 \mathrm{~b} ., 95 \mathrm{c}$.

BLACK RED BALI-Deep, rich, red roots of fine flavor. Uniform shape, early. Pkt., $10 \mathrm{c}$; oz., $20 \mathrm{c}$; $1 / 4$ lb., $45 \mathrm{c}$.

BURPEE'S IMPROVED BLOOD-Smooth, round roots of deep red, which retain their color after cooking. Flesh is fine grained and free from fiber. Easily stored for Winter. Pkt., 10c; oz., 20c; $1 / 41 \mathrm{lb} ., 45 \mathrm{c}$; lb., $\$ 1.00$.

COLUMBIA-Deep, blood-red roots of choicest quality. Roots are Turnip shaped. Pkt., $10 \mathrm{c} ;$ oz., $20 \mathrm{c} ; 1 / 4 \mathrm{lb} ., 50 \mathrm{c}$.

\section{SUGAR BEETS}

WANZLEBEN-Roots 7 to 8 inches long, may be set 5 inches apart in the row. Pkt., $5 \mathrm{c} ;$ oz., $12 \mathrm{c} ; \mathrm{lb} ., 75 \mathrm{c}$. 


\section{MANGELS}

MAMMOTH PRIZE LONG RED-Attains enormous size and is the heaviest cropping of all Mangels. Roots are frequently two feet in length and six inches in diameter. Pkt., $10 \mathrm{c} ; 0 \mathrm{z}, 15 \mathrm{c} ; \mathrm{r} / 2 \mathrm{lb} ., 40 \mathrm{c}$; lb., $60 \mathrm{c}$.

GOLDEN TANKARD-Yields large crops of smooth, yellow roots. Easily harvested. Excellent keeper. Pkt., 5c; oz., 12c;1/2 lb., $40 \mathrm{c} ; \mathrm{lb} ., 60 \mathrm{c}$.

\section{BRUSSELS SPROUTS}

DANISH PRIZE-Pkt., $10 \mathrm{c} ; 0 \mathrm{z} ., 40 \mathrm{c}$.

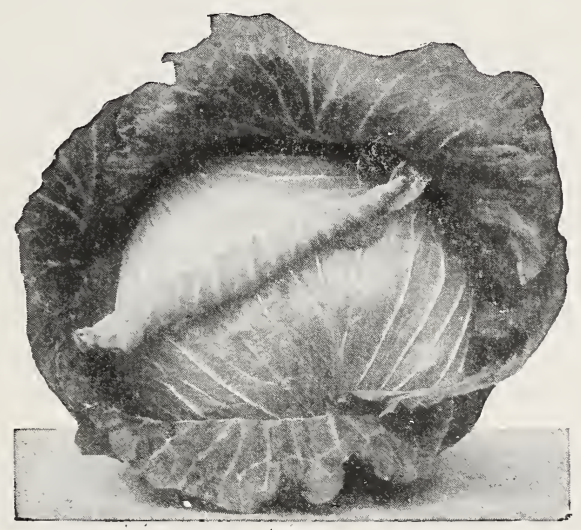

CABBAGE

LOUISVILLE DRUMHEAD-Large, round and compact heads. Drouth resistant; splendid for kraut. Best for late planting. Pkt., 10c; oz., $40 \mathrm{c} ; 1 / 4$ lb., $\$ 1.25$.

EARLY JERSEY WAKEFIELD-Pointed heads, solid and well blanched. Dependable. Pkt., 10c; oz., 30c; 1/4 lb., 90c.

CHARLESTON OR LARGE WAKEFIELD-Has larger head than Early Jersey Wakefield but is about ten days later. Pkt., $10 \mathrm{c}$; oz., 30c; $1 / 4$ lb., 85c; 1/2 lb., $\$ 1.50 ; 1 b ., \$ 2.75$.

EARLY DWARF FLAT DUTCH-A good, short-stemmed, second early variety. Pkt., $10 \mathrm{e} ;$ oz., $25 \mathrm{c} ; 1 / 4 \mathrm{lb}, 75 \mathrm{c} ; \mathrm{lb} ., \$ 2.50$.

SUCCESSION-About three weeks later than Jersey-Wakefield. Heads very large and somewhat flat. A very popular second-early. Pkt., $10 \mathrm{c} ; 0 \mathrm{z} .35 \mathrm{c} ; 1 / 4$ 1b., $\$ 1.00$.

COPENHAGEN MARKET-The heads are large and tightly folded, with very small core, maturing a little later than Jersey-Wakefield. This is the best early roundhead cabbage. Pkt., $10 \mathrm{c} ; 0 \mathrm{z}, 45 \mathrm{c} ; 1 / 4 \mathrm{lb}$. , $\$ 1.30 ; 1 \mathrm{~b} ., \$ 4.25$. 
BURPEE'S SUREHEAD-Large, flat heads of fine, solid texture. Late. Pkt., 10c; oz., 30c; 1/4 lb., 90c.

PREMIUM FIAT DUTCH-Excellent for Winter storing. Heads large and firm. Pkt., 10c; oz., 35c; 1/4 lb., $\$ 1.00$.

ALLHEAD FARLY-Good for Summer, Fall or Winter. The earliest large cabbage. Heads are deep and solid. Pkt., 10c; oz., 35c; $1 / 4$ lb., $\$ 1.00 ; 1 / 2 \mathrm{lb} ., \$ 1.80 ; \mathrm{lb} ., \$ 3.25$.

\section{CHINESE OR CELERY CABBAGE}

As the plants grow and mature very rapidly, cool weather is an essential to the successful growing of Chinese Cabbage. The large, tightly folded heads of tender leaves can be served as cold slaw or with dressing as for lettuce. When boiled the "greens" are even more palatable than cabbage. Sow in August.

WONG BOK-Rather short, broad leaves. Pkt., $10 \mathrm{c}$.

PE-TSAI-Large, narrow heads. Later than Wong Bok. Pkt., $10 \mathrm{c}$.

\section{CARROTS}

OXHEART-Sweet, tender and free from core. The roots are stout and thick. Pkt., $10 \mathrm{c}$; oz., $20 \mathrm{c}$; lib., $\$ 1.00$.

DANVER'S HALF-IONG-The most popular variety and used extensively by market growers. Tender and of good flavor. Pkt., 10c; oz., 15c; lb., $\$ 1.00$.

CHANTENAY-An excellent variety for winter use. The roots grow quickly and are of excellent quality. Pkt., $10 \mathrm{c} ; 0 \mathrm{z} ., 20 \mathrm{c} ; 1 / 4 \mathrm{lb} ., 45 \mathrm{c}$; lb., $\$ 1.20$.

IMPROVED IONG ORANGE-An excellent standard sort for Winter use. The large, orange-red roots are free from core. Extensively grown for stock on account of the great yield. Pkt., 10c; oz., 15c; lb., $\$ 1.00$.

\section{CAULIFLOWER}

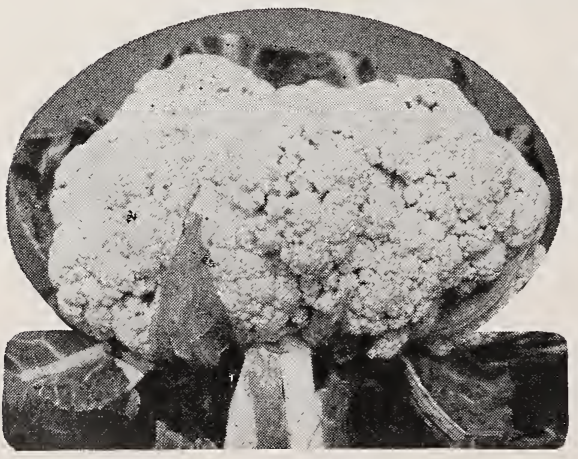

BURPEE'S BEST EARLY-The earliest and best quick-growing Cauliflower. Pkt., $15 \mathrm{c} ; 1 / 4$ oz., $75 \mathrm{c} ; 1 / 2$ oz., $\$ 1.45$.

EARIY SNOWBAII - Heads pure white of excellent quality. Market gardeners claim first place for this variety. Pkt., $15 \mathrm{c} ; 1 / 4$ oz., $75 \mathrm{c}$; $1 / 2$ oz., $\$ 1.45$.

DRY WEATHER-F'or growing in dry locations. Not suitable for forcing. Pkt., $20 \mathrm{c} ; 1 / 4 \mathrm{oz}$., $80 \mathrm{c} ; 1 / 2$ oz., $\$ 1.55$.

\section{CELERIAC}

TURNIP-ROOTED CELERY-The plant forms a large, thick root, highly esteemed as a flavor for soups, stews and other dishes. Pkt., $10 \mathrm{c}$. 


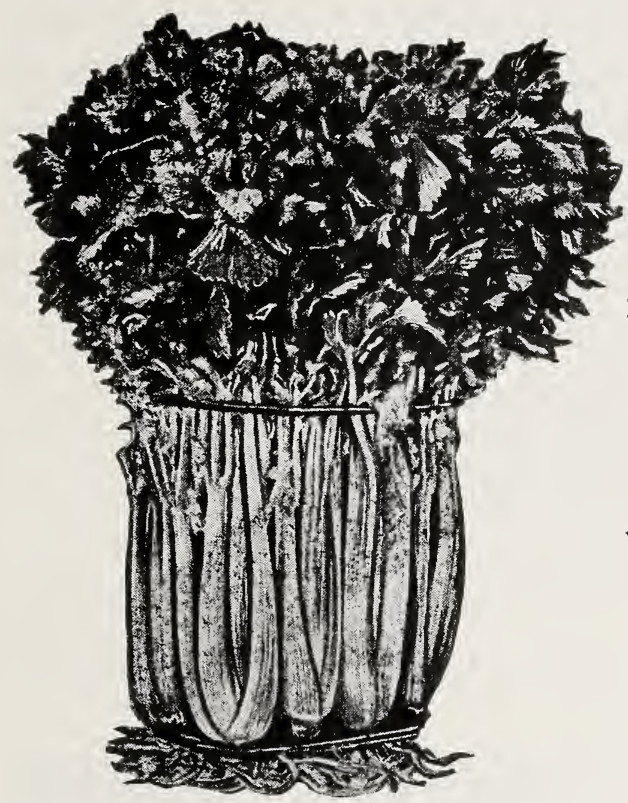

\section{CELERY}

GOLDEN SELF-BLANCHING

Of dwarf, compact growth with thick, heavily ribbed stalks. When blanched the stalks are a clear, waxen yellow, erisp and free from stringiness. Pkt., 20c; 1/2 oz., $45 \mathrm{c}$; oz., $85 \mathrm{c}$.

FORDHOOK - The largest, most solid and finest flavor. ed celery. Of dwarf growth, the stalks are e a sil y blanched. The color is white, the heart alone being tinged yellow. Pkt., 20c; $1 / 2$ oz., $65 \mathrm{c} ;$ oz., $\$ 1.20$.

WHITE PLUME - A very' early sort with white stalks, easily blanched but not recommended for Winter use. Pkt., $10 \mathrm{c} ; 1 / 2$ oz., $20 \mathrm{c} ;$ oz., $35 \mathrm{c}$.

\section{StimUplan T Makes a Wonder Garden}

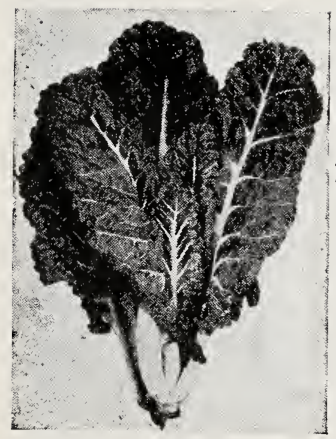

\section{SWISS CHARD}

LUCULLUS-The leaves of this plant are used a greens, the large white ribs are creamed like Asparagus. The culture is much the same an for Beets. Pkt., 10c; oz., 20c; 1/4 lb., $45 \mathrm{c}$.

\section{CHICORY}

WITLOOF OR FRENCH ENDIVE-Used principally as a Winter salad. The seed should be sown in June, the roots lifted in the Fall and kept in a moist, cool place until wanted for foreing. Pkt., 10c; oz., $25 \mathrm{c} ; 1 / 4 \mathrm{lb}$., $70 \mathrm{c}$.

\section{COLLARDS}

A Cabbage-like plant used for greens. Pkt., 5c.

\section{CORN SALAD}

This is a hardy Winter sa'ad, being served like Lettuce or used to garnish meat dishes. Pkt., $10 \mathrm{c}$. 


\section{SWEET CORN}

GOLDEN BANTAM-An early corn of dwarf growth bearing delicious ears of golden yellow color. We consider this the best corn for home use and is extensively used for canning on the cob. Successive plantings may be made up to the first of August. Pkt., $10 \mathrm{c} ; 1 \mathrm{~b} ., 40 \mathrm{c}$.

BLACK MEXICAN-Ears 8 inches long and 8 rowed. One of the sweetest and best varieties for home garden. When mature, the grains are bluish purple. Pkt., 10c; lb., 40c; 2 lb., $75 \mathrm{c}$.

GOLDEN GIANT-A cross between Golden Bantam and Howling Mob. Pkt., $15 \mathrm{c} ; 1 \mathrm{~b} ., 50 \mathrm{c}$.

STOWELL'S EVERGREEN-A good main-crop variety. Very deep, sweet grain. Pkt., $10 \mathrm{c}$; lb., $40 \mathrm{c}$.

EXTRA-EARLY ADAMS-Although this corn is not a true sugar corn, it is of good flavor and much used for extra early planting. Pkt., 10c; lb., $30 \mathrm{c}$.

ADAMS EARLY-Larger than the Extra-Early Adams and about 10 days later. Pkt., $10 \mathrm{e} ; 1 \mathrm{~b} ., 30 \mathrm{c}$.

COUNTRY GENTLEMAN-Large ears of very fine quality. The small cobs are irregularly covered with long, slender, white grains. A main erop variety. Pkt., $10 \mathrm{c} ; 1 \mathrm{~b} ., 40 \mathrm{c}$.

HOWLING MOB-A superb white corn, maturing right after Golden Bantam and making a perfect succession. Pkt., $10 \mathrm{c} ; \mathrm{lb} ., 40 \mathrm{c}$.

WHITE EVERGREEN-Ears are large as Stowell's Evergreen, maturing 5 days earlier and of superior quality. Pkt., $10 \mathrm{c}$; $1 / 2$ lb., 30c; 1b., $50 \mathrm{c}$.

EARLY FORDHOOK - Earlier than Golden Bantam, this is considered the finest early white, sweet corn. Pkt., 10c; $1 / 2$ lb., $30 \mathrm{c} ; 1 \mathrm{~b} ., 50 \mathrm{c}$.

FARLY NORTHERN FIELD This variety is not a sugar corn but is here listed as a special strain used by market gardeners for early roasting ears. Pkt., $10 \mathrm{c} ; 1 \mathrm{~b} ., 25 \mathrm{c}$.

HICKORY KING-This is an old favorite field corn used for roasting ears. When young and tender, the ears are delicious. Large, flat grains, very small cob. Pkt., $10 \mathrm{c}$; lb., $30 \mathrm{c}$.

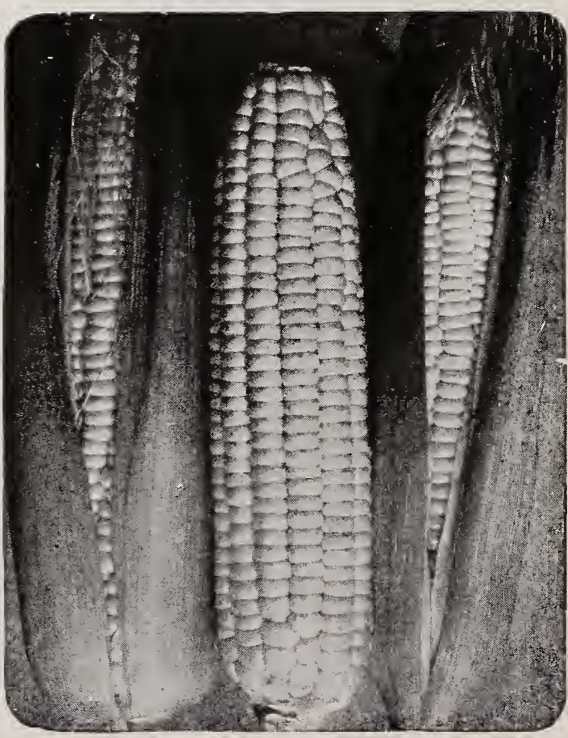

WHITE EVERGREEN

\section{POP CORN}

WHITE-RICE-Pkt., $10 \mathrm{c} ; 1 / 2 \mathrm{lb}, 20 \mathrm{c} ; \mathrm{lb} ., 35 \mathrm{c}$.

QUEEN'S GOLDEN-Pkt., $10 \mathrm{c} ; 1 / 2 \mathrm{lb} ., 20 \mathrm{c} ; 1 \mathrm{~b} ., 35 \mathrm{c}$. 


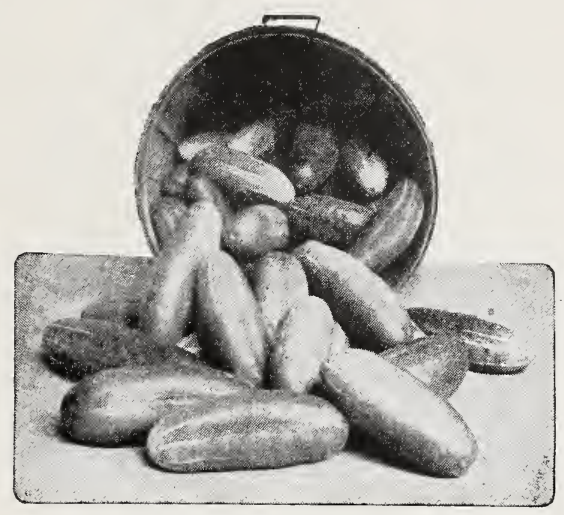

\section{CUCUMBER}

\section{FORDHOOK WHITE SPINE-(Crop Failed.)}

EXTRA EARLY WHITE SPINE-An extremely early variety of handsome appearance. Unequaled as a table variety and popular with market gardeners. Pkt., 10c; oz., 25e; $1 / 4$ lb., $65 \mathrm{c} ; 1 / 2 \mathrm{lb} ., \$ 1.00 ; 1 \mathrm{~b} ., \$ 1.75$.

LONDON OR IMPROVED LONG GREEN-The fruits often attain a length of 10 to 12 inches. Of excellent quality. The young fruits make very good pickles. Pkt., $10 \mathrm{c} ;$ oz., $25 \mathrm{c} ; 1 / 4 \mathrm{lb} ., 65 \mathrm{e} ; 1 / 2 \mathrm{lb} ., \$ 1.00$.

FORDHOOK FAMOUS -An immense and handsome cucumber. The most fleshy and finest in flavor of the White Spine type. Pkt., 10c; oz., $35 \mathrm{c} ; 1 / 4 \mathrm{lb}$., $95 \mathrm{c}$.

DAVIS PERFECT-Intensely rich, dark green skin. Superb for slicing, very prolific and of very attractive appearance. Pkt., $10 \mathrm{c} ;$ oz., $20 \mathrm{c}$; $1 / 4 \mathrm{lb} ., 75 \mathrm{c}$.

EARLY FORTUNE-This is a leading market garden variety. The vigorous vines set fruits very freely. Fully grown, the fruits measure 9 inches in length, slightly tapering at both ends. Pkt., $10 \mathrm{c} ; 0 \mathrm{z} ., 25 \mathrm{c}$; $1 / 4 \mathrm{lb}$., $65 \mathrm{c}$; $1 / 2 \mathrm{lb}$., $95 \mathrm{c}$; lb., $\$ 1.60$.

BOSTON PICKLING OR EXTRA EARLY GREEN PROLIFIC-Full grown fruits measure 4 to 5 inches in length. If kept gathered, the vines will continue to bear throughout the season. Pkt., 10c; oz., 25c; $1 / 4$ lb., $60 \mathrm{c} ; 1 / 2 \mathrm{lb} ., 90 \mathrm{c} ; \mathrm{lb} ., \$ 1.50$.

WEST INDIA GHERKIN-A very prolific, small-fruited variety, used exclusively for pickles. The small fruits are thickly covered with spines. Pkt., $10 \mathrm{c}$.

FORDHOOK PICKLING CUCUMBER-A prolific and continuous bearer. Pure white flesh, crisp and juicy. Pkt., $10 \mathrm{c} ; 0 \mathrm{z} ., 35 \mathrm{c}$.

\section{EGG PLANT}

BLACK BEAUTY-The earliest and best of all large fruited Egg Plants. Pkt., $15 \mathrm{c} ; 1 / 2$ oz., $30 \mathrm{e}$; oz., $50 \mathrm{e}$. 


\section{ENDIVE}

CREFN CURIED-The finely cut leaves are a rich green in color, but blanches to ereamy white. Pkt., $10 \mathrm{c} ;$ oz., $20 \mathrm{c} ; 1 / 4 \mathrm{lb} ., 55 \mathrm{c} ; 1 \mathrm{lb}$., $\$ 1.75$.

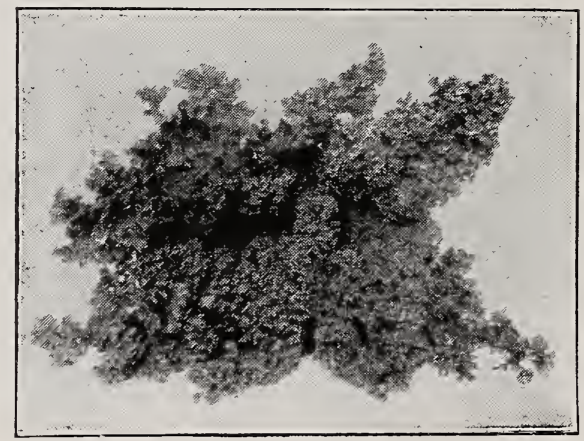

\section{KALE}

DWARF GREEN CURLED SCOTCH-Low growing, compact with finely curled leaves. For Fall and Spring greens. Pkt., 10c;oz., 15c; $1 / 4$ lb., $25 \mathrm{c} ; 1 \mathrm{lb} ., 85 \mathrm{c}$.

DWARF SIBERIAN-A very hardy variety, will survive through severe Winter weather out-of-doors. The leaves are large and broad. Pkt., $5 \mathrm{c} ; 0 \mathrm{z} ., 10 \mathrm{c} ; 1 / 4 \mathrm{lb} ., 25 \mathrm{c} ; 1 / 2 \mathrm{lb} ., 60 \mathrm{c} ; 1 \mathrm{~b} ., 85 \mathrm{c}$.

TALL CURLED SCOTCH-Tall plants with nicely curled leaves. Pkt., $10 \mathrm{c} ; 0 \mathrm{z} ., 20 \mathrm{c} ; 1 / 4 \mathrm{lb} ., 45 \mathrm{c}$.

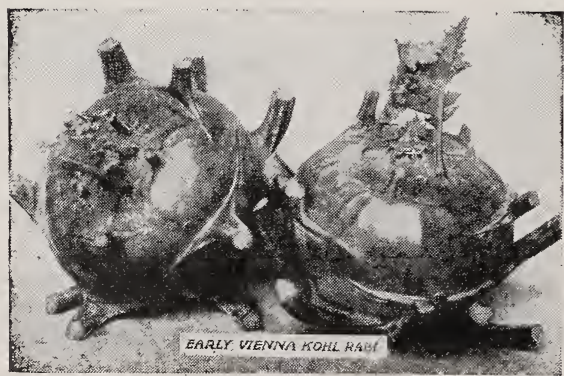

\section{KOHL RABI}

EARIY WHITE VIENNA-An early, short-topped strain. The flesh is erisp and sweet. Pkt., $10 \mathrm{c}$.

\section{LEEK}

LONG MEZIERES-This is a French variety that does well in this climate. The extra long stems blanch readily to a snow white. Pkt., 10c. 


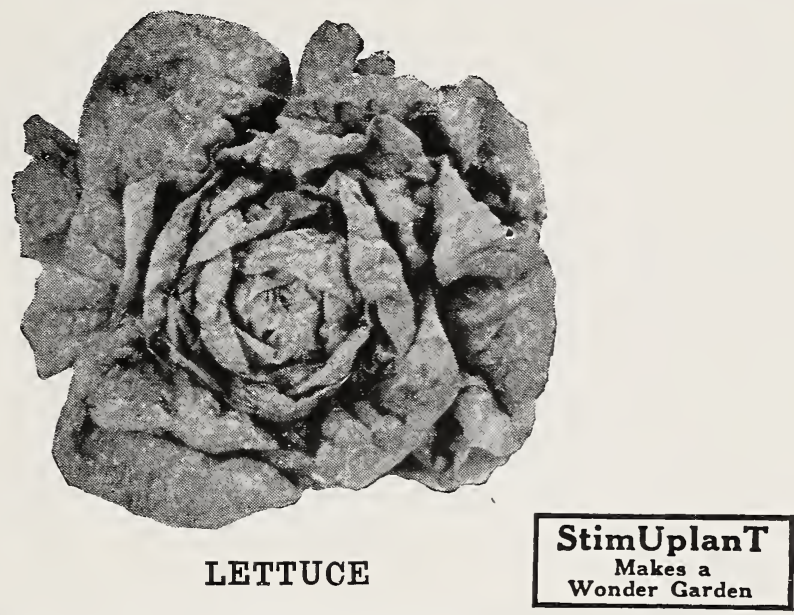

GRAND RAPIDS-This variety does not make a tightly folded head but very compact bunches of finely crimped leaves. Excellent for greenhouse forcing. Pkt., $10 \mathrm{c}$; oz., $30 \mathrm{c} ; \mathrm{I} / 4 \mathrm{lb}$., $85 \mathrm{c}$.

BIG BOSTON-Enormous heads of tightly folded leaves. Will head particularly well in cool weather. Pkt., $10 \mathrm{c}$; oz., $30 \mathrm{c} ; 1 / 4 \mathrm{lb}, 90 \mathrm{c}$; $1 / 2 \mathrm{lb} ., \$ 1.65$.

WAYAHEAD-This is an early heading variety, with a tightly folded heart which blanches a buttery yellow tint. Well suited for market. Pkt., 10c; oz., 25c; 1/4 lb., $75 \mathrm{c} ; 1 / 2 \mathrm{lb} ., \$ 1.40$.

MAY KING-Easily forced in frames in the Spring. A sure header with light yellow heart, juicy, brittle and excellent flavor. Pkt., 10c; oz., $25 \mathrm{c}$.

FARIY CURLED SIMPSON OR SILESIA-This is a white-seeded Simpson. Crisp, loose heads of crumpled and frilled leaves. Pkt., 10c; oz., $25 \mathrm{c} ; 1 / 4 \mathrm{lb} ., 70 \mathrm{c}$.

BIACK-SEEDED SIMPSON-A standard variety of fine quality. Makes large bunches of loose well crumpled and frilled leaves. Pkt., 10c; oz., $25 \mathrm{c} ; 1 / 4 \mathrm{lb}, 70 \mathrm{c}$.

CAIIFORNIA CREAM BUTTER-Heads large and solid. The heart is tender and crisp. Pkt., 10c; 0z., 25c.

BUTTERHEAD-A large, solid head of excellent quality. Adapted to widely different conditions of soil and climate. Pkt., $10 \mathrm{c}$; oz., $25 \mathrm{c}$.

HANSON-A sure heading variety with solid heart. Crisp, mild and tender. Pkt., 10c; oz., $25 \mathrm{c}$.

BRITTLE ICE-(Cannot supply.)

ICEBERG-Compact head which blanches to a white heart. Well known in the markets. Outer leaves are curled and fringed. Pkt., 10c; oz., $30 \mathrm{c} ; \mathrm{lb} ., \$ 2.75$.

\section{COS LETTUCE}

DWARF WHITE HEART-Cos Lettuce is grown prineipally on account of its mild flavor, crispness and peculiar upright growth. Pkt., 10c; oz. 25 c. 


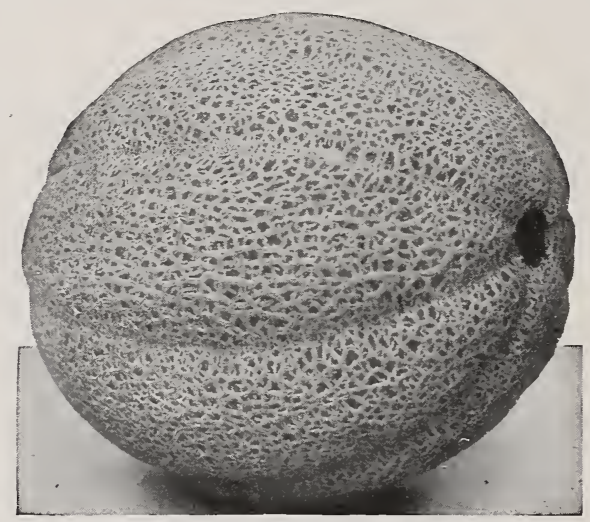

MUSK MELON

HEARTS OF GOLD-Rapidly gaining popularity with market gardeners. The fruits, of nice size and uniform shape, are distinctly ribbed and covered with a fine gray netting. Salmon flesh. Pkt., 10c; oz., 25c; $1 / 4$ lb., $60 \mathrm{c} ; 1 \mathrm{~b} ., \$ 1.50$.

NETTED GEM OR ROCKY FORD-This variety is so sweet and luscious that it is easily the most popular of all green-fleshed melons. Prolific. Pkt., $10 \mathrm{c}$; 0z., $20 \mathrm{c}$; $1 / 4$ lb., $50 \mathrm{c}$; $1 / 2 \mathrm{lb}$., $75 \mathrm{c}$; lb., $\$ 1.25$.

FORDHOOK-Very thick, orange-yellow flesh, well ribbed and netted, rather flattened at ends. Pkt., $10 \mathrm{c} ; 0 \mathrm{z} ., 25 \mathrm{c} ; 1 / 4 \mathrm{lb} ., 60 \mathrm{c} ; 1 / 2 \mathrm{lb}, 90 \mathrm{c}$; lb., $\$ 1.50$.

EMERAID GEM-Very early, coming in ahead of Rocky Ford. Smooth, green skin, well ribbed. Flesh is a rich, salmon color, sweet and luscious. Pkt., $10 \mathrm{c} ; 0 \mathrm{z} ., 25 \mathrm{c} ; 1 / 4$ lb., $60 \mathrm{c} ; 1 / 2$ lb., $85 \mathrm{c} ; 1 \mathrm{~b} ., \$ 1.40$.

FXTRA EARLY HACKENSACK-The melons are of very splendid appearance, ribbed and netted. Flesh is sweet and of good quality. Pkt., $10 \mathrm{c}$; oz., $20 \mathrm{c}$.

SPICY-Melons from 8 to 10 inches long. Flesh is deep and of sugary flavor. Pkt., $10 \mathrm{c} ; 0 \mathrm{z}, 35 \mathrm{c}$.

BANANA-The fruits attain a length of 15 or more inches. The salmon flesh is thick and delicious. Excellent for home garden. Pkt., 10c; oz., $25 \mathrm{c}$.

HONEY DEW-Very thick, green flesh, ripening to the rind. Skin smooth and free from netting. An excellent keeper. Pkt., 10c; 0z., 25c; $1 / 4$ lb., $65 \mathrm{c}$.

SALMON TINT POLLOCK 10-25-Thick, luscious flesh of genuine salmon tint, shading to green near the rind. A splendid market sort. Pkt., $10 \mathrm{c}$; 0z., $20 \mathrm{c} ; 1 / 4$ lb., $50 \mathrm{c} ; 1 / 2$ lb., $70 \mathrm{c}$.

TIP TOP-Flesh is a rich, deep salmon. The light green skin is lightly netted. A sweet, juicy melon, maturing somewhat late. Popular with market gardeners. Pkt., 10c; oz., $20 \mathrm{c} ; 1 / 4$ lb., $50 \mathrm{c} ; 1 \mathrm{~b} ., \$ 1.50$.

MONTREAL GREEN-Melons are deeply ribbed and densely netted. F'lesh is green, thick and of superior quality. Pkt., $10 \mathrm{c} ; 0 \mathrm{z} ., 25 \mathrm{c} ; 1 / 41 \mathrm{~b} ., 50 \mathrm{c}$. 


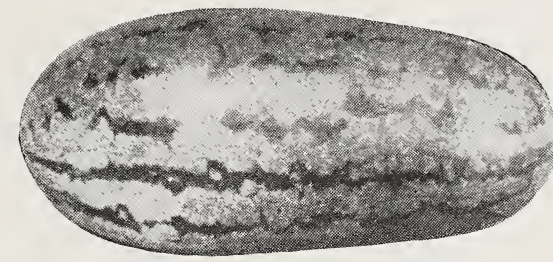

WATERIMELONS

\section{StimUplanT Makes a Wonder Garden}

FORDHOOK EARLY-Pkt., $10 \mathrm{c} ;$ oz., $25 \mathrm{c} ; \mathrm{I} / 4 \mathrm{lb} ., 50 \mathrm{c}$.

SUGAR STICK-A large melon of fine flavor. The skin is light green with dark markings. The rind is thin and tough, shipping well. Pkt., $10 \mathrm{c} ;$ oz., $25 \mathrm{c} ; 1 / 4$ lb., $50 \mathrm{c} ; 1 / 2$ lb., $75 \mathrm{c} ; 1 \mathrm{~b} ., \$ 1.25$.

HALBERT HONEY-This is essentially a home variety. The fruits measure 18 to 20 inches in length and 6 to 8 in diameter. The flesh is crimson and very sweet. Skin is glossy deep green. Pkt., 10c: oz., $25 \mathrm{c} ; 1 / 4 \mathrm{lb} ., 50 \mathrm{c} ; 1 \mathrm{~b} ., \$ 1.25$.

KLECKLEY SWEETS-Our stock of this seed is grown by the originator. A very desirable sort for home or nearby market. Very thin rind, dark glossy skin. Flesh solid with white seeds close to the rind. Pkt., 10c; oz., $25 \mathrm{c} ; 1 / 4$ lb., $50 \mathrm{c} ; 1 \mathrm{~b} ., \$ 1.25$.

TOM WATSON-A tough rind shipping melon. Large in size and of attractive appearance. Flesh is a rich red with white seeds. Quality excellent. Pkt., $10 \mathrm{c}$; oz., $15 \mathrm{c} ; 1 / 4$ lb., $35 \mathrm{c} ; 1 \mathrm{lb} ., 75 \mathrm{c}$.

IRISH GREY-The thin rind is very tough, making this an excellent shipping melon. The skin is a greenish gray, the flesh bright red, crisp and tender. This melon bids fair to become very popular. Pkt., $10 \mathrm{c} ;$ oz., $15 \mathrm{c} ; 1 / 4$ lb., $35 \mathrm{c} ; 1 \mathrm{~b} ., \$ 1.00$.

EXCEL-Very popular in the South as a market sort. A good shipper. Pkt., $10 \mathrm{c} ;$ oz., $15 \mathrm{c} ; 1 / 4$ lb., 35c; lb., $\$ 1.00$.

\section{MUSTARD}

SOUTHERN GIANT CURLED-Vigorous and hardy plants of upright growth. The light green leaves are tinged with yellow, much frilled and crumpled at the edge. Pkt., $10 \mathrm{c} ;$ oz., $20 \mathrm{c} ; 1 / 41 \mathrm{~b} ., 45 \mathrm{c} ; 1 \mathrm{~b} ., \$ 1.25$.

FORDHOOK FANCY-Makes delicious greens. The dark green leaves are curled and plumed. Pkt., $10 \mathrm{c} ;$ oz., $20 \mathrm{c} ; 1 / 4$ lb., $45 \mathrm{c} ; 1 \mathrm{~b} ., \$ 1.50$.

\section{OKRA}

DWARF PROLIFIC-The dwarf, stocky plants bear an enormous crop. The pods mature early and are very tender. Pkt., $10 \mathrm{c} ; 0 \mathrm{z.}, 15 \mathrm{c}$; $1 / 4$ lb., $35 \mathrm{c} ; 1 \mathrm{~b} ., 75 \mathrm{c}$.

WHITE VELVET-A tall-growing plant with smooth velvety pods. Pkt., $10 \mathrm{c} ; 0 \mathrm{z} ., 15 \mathrm{c} ; 1 / 4$ lb., $30 \mathrm{c} ; 1 \mathrm{~b} ., 65 \mathrm{c}$.

KLECKLEY'S FAVORITE-Plants are $2 \frac{1}{2}$ to 3 feet high. Smooth, white pods. Pkt., $10 \mathrm{c}$; oz., $15 \mathrm{c}$; lb., $75 \mathrm{c}$.

PERFECTED PERKINS LONG-POD-A strong growing variety bearing an abundance of large pods. Good quality. Pkt., 10c; oz., 15c; $1 / 4$ lb., $35 \mathrm{c}$; $1 / 2$ lb., 50 c ; 1b., $75 \mathrm{c}$. 


\section{ONIONS}

MAMMOTH SILVER KING-Pkt., 10c; oz., $35 \mathrm{c}$.

PRIZE-TAKER-Under favorable conditions this variety will grow to enormous size, attaining a weight of 4 pounds or more. Mild and sweet. Pkt., $10 \mathrm{c} ; 0 z ., 30 \mathrm{c} ; 1 / 4$ lb., $75 \mathrm{c} ; 1 / 2$ lb., $\$ 1.15$.

EARLIEST WHITE QUEEN-A superb pickling onion. Pure white and mild in flavor. Pkt., $10 \mathrm{c}$; oz., $35 \mathrm{c}$.

RED WETHERSFIELD-The outer skin is deep, rich, purplish red. White flesh tinged with pink. Pkt., $10 \mathrm{c}$.

YELLOW GLOBE DANVERS-A good Onion, both for home and market gardens. A good Winter keeper. Pkt., $10 \mathrm{c} ; 0 \mathrm{z} ., 30 \mathrm{c} ; 1 / 4 \mathrm{lb} ., 70 \mathrm{c}$.

\section{ONION SETS}

WHITE SETS-Grown from choice strain of White Silverskin. Mild and sweet; lb., $40 \mathrm{c}$., postpaid.

YELLOW SETS-These will produce handsome bulbs early in the Summer. Splendid for Winter use; lb., $30 \mathrm{c}$, postpaid.

\section{PARSLEY}

EXTRA CURLED DWARF-The moss-like leaves of bright green color are finely curled and are excellent for garnishing or flavoring. Pkt., $10 \mathrm{c} ;$ oz., $20 \mathrm{c} ; 1 / 4$ lb., $40 \mathrm{c} ; 1 / 2$ lb., $65 \mathrm{c}$.

PLAIN OR SINGLE-An enormous yielder of very excellent flavor. Will stand the Winter with a little protection. Pkt., $10 \mathrm{c} ; 0 \mathrm{z} ., 15 \mathrm{c} ; 1 / 4$ lb., $35 \mathrm{c}$.

\section{PARSNIPS}

GUERNSEY-Considered the best and most productive. The roots are medium long with broad shoulder tapering down to point. Pkt., $10 \mathrm{c}$; oz., $20 \mathrm{c} ; 1 / 4$ lb., $45 \mathrm{c} ; 1 \mathrm{~b} ., \$ 1.00$.

LONG SMOOTH HOLIOW CROWN-The roots are long and tapering. Require deep soil for perfect development. Pkt., 10c; oz., 20c; 1/4 lb., $45 \mathrm{c} ; \mathrm{lb} ., \$ 1.00$.

\section{PEANUTS}

MAMMOTH BUSH-Thrive best in light, sandy soils. The culture is much the same as for beans. The nuts are truly mammoth. $1 / 2 \mathrm{lb} ., 25 \mathrm{c}$; lb., $40 \mathrm{c}$.

\section{PEAS}

*ALASKa OR EARIIEST OF ALL-Vines grow 20 to 30 inches tall. Very early smooth, blue pea. Quite popular with market gardeners and canners. Pkt., $10 \mathrm{c}$; 1/2 lb., 20c; lb., 40c; 2 lbs., 75c.

*BURPEE'S BEST EXTRA EARLY-Vines 18 to 24 inches in height. Pods are well filled with smooth peas which may be gathered at one picking. Pkt., $10 \mathrm{c} ; 1 / 2 \mathrm{lb}, 25 \mathrm{c}$; lb., $50 \mathrm{c} ; 2 \mathrm{lbs} ., 75 \mathrm{c}$.

GRADUS EXTRA EARLY-The best early wrinkled pea. Growth 21/2 to 3 feet. Pods large. Popular in the markets; lb., $40 \mathrm{c} ; 2$ lbs., $70 \mathrm{c}$.

THOS. IAXTON-Growth is identical with Gradus but matures about 4 days later; lb., $40 \mathrm{c}$; 2 lbs., 70c.

PREMIUM GEM-Sweet and delicious Peas abundantly borne on dwarf growth; lb., $40 \mathrm{c} ; 2$ lbs., $75 \mathrm{c}$.

ITTLE MARVEL-Vines 15 inches in height. The well-filled pods are square at the end. A dependable variety; lb., $40 \mathrm{c} ; 2$ lbs., $75 \mathrm{c}$. 


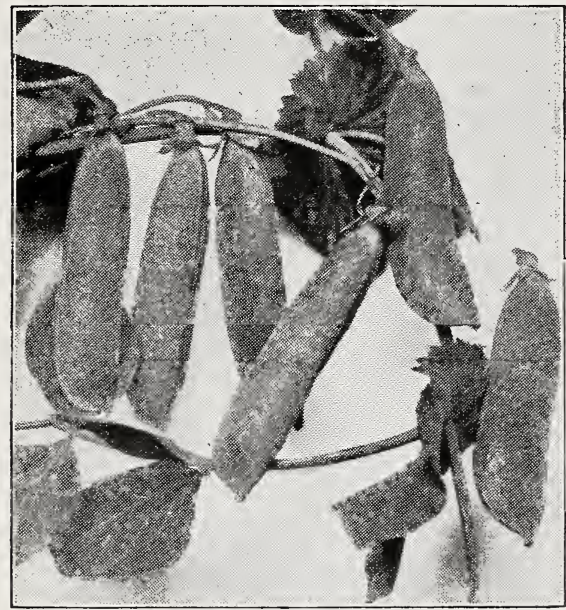

IIITARAK

NOTT'S EXCELSIOR-So closely are the large Peas packed in the pods that they are flattened against each other. Vines 1 foot high. Good for home or market garden; 1b., 40e; 2 lbs., $75 \mathrm{c}$.

TELEPHONE-A sturdy, productive sort, growing 4 to 5 feet tail. The pods and Peas are large. A main crop variety of excellent quality; lb., $35 \mathrm{c}$; 2 lbs., $70 \mathrm{c}$.

CHAMPION OF ENGLAND-One of the richest and best flavored of the late Peas. Height 4 to 5 feet. Matures after Telephone; lb., $40 \mathrm{c}$; 2 lbs., $75 \mathrm{c}$.

*CLAUDIT-Extra large pods, well filled. Smooth, blue seed; lb., 40c; 2 lbs., $75 \mathrm{c}$.

BLUE BANTAM-An excellent dwarf growth, large-podded variety of the Laxtonian type. Height 15 inches. Early and enormous eropper. The best first-early dwarf wrinkled Pea; lb., $50 \mathrm{e} ; 2$ lbs., $90 \mathrm{c}$.

LAXTONIAN-On the order of Gradus but more dwarf and earlier. Height 18 inches. Pointed pods $33 / 4$ inches long; lb., $40 \mathrm{c} ; 2$ lbs., $75 \mathrm{c}$.

*Smooth-seeded varieties which may be planted earlier than the wrinkled sorts. The latter will not stand cold, wet ground.

\section{PEPPERS}

SWEET UPRIGHT-The fruits are borne stiffly erect. Thick, sweet flesh. Color when ripe is a glowing scariet. Pkt., $15 \mathrm{c} ; 1 / 2$ oz., $30 \mathrm{c}$.

SWEET-MEAT GIORY-The thick, solid meat is sweet and never hot. When ripe, the fruits are crimson scarlet and conical in shape, measuring 2 inches across at the stem end and 3 to $3 \frac{1}{2}$ inches in length. Pkt., 15e; oz., 60e.

CHINESE GIANT-The largest mild red Pepper and an excellent variety for home gardens. Fruits pendant, thick and blocky. Pkt., 15e; oz., $65 \mathrm{c}$. 
RUBY KING-Bears fine crop of fruits on dwarf, compact bushes. Sweet and mild Peppers, 4 to 6 inches in length and 3 to 4 inches through. Valuable for home or market. Pkt., $10 \mathrm{c}$; oz., $40 \mathrm{c}$.

IONG RED CAYENNE-A hot and pungent red Pepper. The true Cayenne. Pkt., 10c; oz., $40 \mathrm{c}$.

\section{PUMPKINS}

SMALL SUGAR-There is no better Pumpkin for pies. 10 inches in diameter, slightly ribbed and flattened at the ends. Pkt., 10c; oz., 20c.

BIG TOM-Vines vigorous and very prolific. Fruits are 15 to 20 inches in diameter, round or globe-shaped. Orange-yellow flesh. Pkt., 10e; lb., $80 \mathrm{c}$.

KENTUCKY FIELD-Thick flesh of fine quality. Large fruits. Pkt., 10c; oz., $15 \mathrm{e} ; 1 / 4$ lb., $20 \mathrm{c} ; \mathrm{lb} ., 40 \mathrm{c}$.

GENUINE MAMMOTH-On account of its size, this variety is often grown for exhibition purposes. Our seed is of the genuine MAMMOTH strain. The flesh is thick, fine grained and tender. Pkt., 10c; oz., $25 \mathrm{c} ; 1 / 4$ lb., 65e; $1 / 2$ lb., $\$ 1.00 ; \mathrm{lb} ., \$ 1.75$.

GOLDEN OBLONG-A very productive variety with excellent keeping qualities. 15 to 20 inches in length and 8 to 10 inches in diameter. Pkt., 10c; 0z., 25c; 1/4 lb., 50c; 1/2 lb., 75c; lb., $\$ 1.25$.

GREEN STRIPED CUSHAW-The meat is of rich, yellow color, tender and of fine flavor. Skin a creamy, white mottled green. Pkt., 10c; oz., $20 \mathrm{c} ; \mathrm{r} / 4$ lb., $45 \mathrm{c}$.

\section{RADISHES}

SCARIET BUTTON-An extra-early, round, red Radish of first class quality. Pkt., $10 \mathrm{c} ; 0 \mathrm{z} ., 25 \mathrm{c}$.

RAPID RED-The quickest growing "Red Button" Radish. Flesh pure white. Pkt., 10c; oz., $25 \mathrm{c}$.

HAILSTONE-The quickest maturing white, round Radish. Ready for the table in less than three weeks from planting. Pkt., 10c; oz., $20 \mathrm{c}$.

SCARLET GLOBE-Ready for table in 4 or 5 weeks. Medium size and attractive appearance. Plant in warm, rich soil. Pkt., 10c; oz., 20c; $1 / 4 \mathrm{lb} ., 45 \mathrm{c}$.

CRIMSON GIANT GLOBE-The flesh is crisp, white and of mild flavor. Grows quickly to large size. Deep erimson skin. Pkt., 10c; oz., $20 \mathrm{c}$.

SCARLFT TURNIP WHITE TIP-Small, round roots with scarlet top and clear, white base. Popular as a market garden variety. Pkt., 10c; oz., $20 \mathrm{c} ; 1 / 4 \mathrm{lb}$., $40 \mathrm{c}$.

FRENCH BREAKFAST-Of true oblong or olive shape. Bright rose scarlet with white tip. F'or home or market garden. An excellent forcer. Pkt., $10 \mathrm{e} ;$ oz., $20 \mathrm{e}$. 
BARIY LONG SCARIET SHORT TOP $\longrightarrow$ Roots six inches in length, maturing in 4 to 5 weeks. The flesh is agreeably pungent, crisp and tender. Pkt., $10 \mathrm{c}$; oz., $20 \mathrm{c}$.

WHITE ICICLE-This is the most popular long, white Radish for either home or market garden. The flesh is crisp and tender. Pkt., 10c; oz., $20 \mathrm{c}$.

WHITE STRASSBURG-Distinctly a Summer variety. The roots measure 4 to 5 inches in length, thick at the shoulder and abruptly tapering. Skin and flesh pure white. Pkt., 10c; oz., $20 \mathrm{c}$.

\section{WINTER RADISHES}

WHITE CHINESE-Plant seed during July and August. The roots may be stored in moist sand for Winter use. Flesh crisp and tender. This is the least pungent of the Winter Radishes. Pkt., 10c;0z., 20c.

IONG BIACK SPANISH-Roots average 8 or 9 inches in length. Skin black but flesh is pure white. Will keep all Winter. Pkt., 10c; oz., $25 c$.

\section{RHUBARB ROOTS}

MYATT'S VICTORIA-Roots planted in the Spring in good, rich soil will make vigorous growth. Stalks should not be cut till the following year. Roots $15 \mathrm{c}$ each; dozen, $\$ 1.25$.

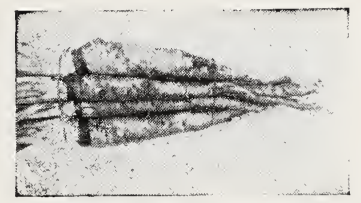

SALSIFY

MAMMOTH SANDWICH ISLAND-This variety, grown for Fall and Winter use, is far superior to the old variety. Although of large size the roots are of fine quality and excellent flavor. Pkt., 10c; oz., 35c.

\section{SPINACH}

VICTORIA-Leaves are large, thick and much wrinkled. A good yielder, quality fine. Pkt., $10 \mathrm{c}$; oz., $15 \mathrm{c} ; 1 / 4$ lb., $20 \mathrm{c} ; 1 \mathrm{lb} ., 40 \mathrm{c}$.

BLOOMSDALE SAVOY-A very early and productive variety. Will go quickly to seed in hot weather. Leaves are crumpled and curled. Pkt., 10c; oz., $15 \mathrm{c} ; 1 / 4 \mathrm{lb} ., 20 \mathrm{c} ; 1 \mathrm{~b} ., 40 \mathrm{c}$.

NEW ZEALAND-This is not a true Spinach but a plant bearing an abundant crop of tender, thick leaves which, according to many, is superior to the ordinary spinach. When the young shoots are cut, the plant will continue to grow until frost. Pkt., 10c; oz., 20c; $1 / 4$ lb., $40 \mathrm{c}$. 


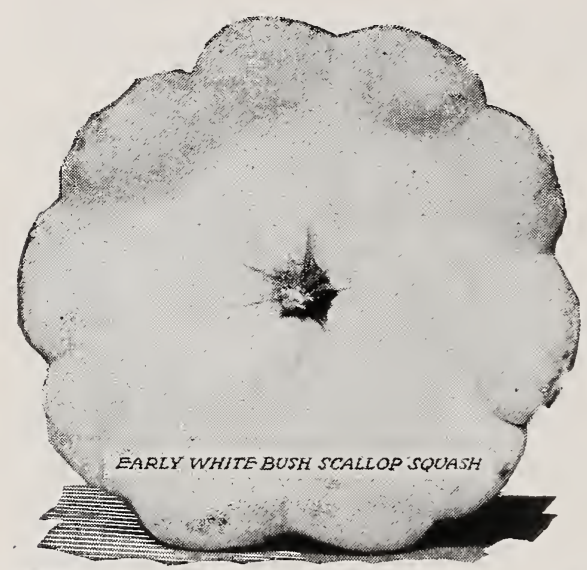

SQUASH

EARLY WHITE BUSH-This is the old-fashioned cymling. A very early sum. mer variety, flattened and scalloped. Skin creamy white. Pkt., 10c; oz., $20 \mathrm{c}$.

GOLDEN SUMMER CROOK. N E C K - Of true bush growth, the fruits are about a foot long, warted and of rich orange color. Pkt., 10c; oz., $20 \mathrm{c} ; 1 / 4$ lb., $50 \mathrm{c}$.

FORDHOOK-Small, oblong fruits measuring 8 to 10 inches borne on vigorous running vines. Fine, buttery flavor. Pkt., $10 \mathrm{c}$; oz., $25 \mathrm{c} ; 1 / 4 \mathrm{lb} ., 60 \mathrm{c}$.

HUBBARD-A splendid keeper, now extensively grown for Winter use. The running vines produce large, warted fruits of a dark green color. Pkt., 10c; oz., 25c; 1/1 lb., 60e.

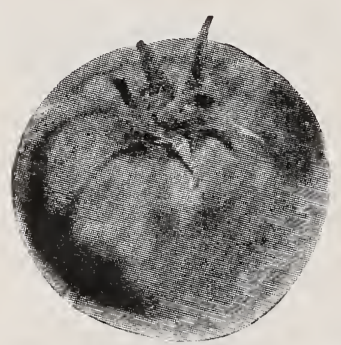

\section{TOMATOES}

STONE-Large, smooth, solid fruits of deep scarlet. A main-crop variety. Pkt., $10 \mathrm{c}$; $1 / 2$ oz., $25 \mathrm{c} ;$ oz., $40 \mathrm{c}$.

SUNNYBROOK EARLIANA-Earliest of all red Tomatoes. Smooth, scarlet fruits. Excellent for early market. Pkt., $10 \mathrm{c} ; 1 / 2 \mathrm{oz}$., $35 \mathrm{c} ; \mathrm{oz} ., 60 \mathrm{c}$.

CHALK'S EARLY JEWEL-Best for early home garden. Fruits large, smooth and of fine flavor. Ten days later than Earliana. Pkt., 10c; $1 / 2$ oz., $25 \mathrm{c} ; 0 \mathrm{z} ., 40 \mathrm{c}$.

SUCCESS-A good canner for the South. Handsome, bright red. Productive. Pkt., 10c; 1/2 oz., 20c; oz., $30 \mathrm{c}$.

MATCHLESS-A rich cardinal red tomato of large size with an unusual amount of firm, solid meat. Sub-acid, main erop variety. Pkt., 10c; $1 / 2$ oz., $25 \mathrm{c} ;$ oz., $45 \mathrm{c}$.

BONNY BEST-Bears uniform, solid fruits, somewhat smaller than Chalk's Jewel and about a week earlier. Pkt., 10c; 1/2 0z., 25c; oz., $40 \mathrm{c}$.

JOHN BAER-An early, red tomato of the Chalk's Jewel type. Very productive. Pkt., $10 \mathrm{c}$; $1 / 2$ oz., $20 \mathrm{c}$; oz., $30 \mathrm{c}$.

IIVINGSTON'S GLOBE-True globe-shaped fruits of even size. Attractive purplish-red. Pkt., $10 \mathrm{c} ; 1 / 2$ oz., $25 \mathrm{c} ; \mathrm{oz} ., 45 \mathrm{c}$.

DWARF CHAMPION-Dwarf, compact, early growth. Medium size pink fruits. Pkt., $10 \mathrm{c} ; 1 / 2$ oz., $15 \mathrm{c}$; oz., $25 \mathrm{c}$.

DWARF GIANT-The largest fruited of all dwarf tomatoes. Solid meat of sweet flavor, showing no trace of core. Excellent for home use. Pkt., $10 \mathrm{c} ; 1 / 2$ oz., $40 \mathrm{c}$; oz., $75 \mathrm{c}$. 
JUNE PINK-Identical with Earliana, except that the fruits are purple or pink. Slightly acid. Pkt., 10c; oz., 40c.

TRUCKER'S FAVORITE-This is a main-crop pink or purple variety of attractive appearance, solid meat and matures with Matchless. Pkt., $10 \mathrm{c} ; 0 \mathrm{z} ., 45 \mathrm{c}$.

PONDEROSA-One of the best for home use. The fruits are unusually large and of crimson color. Flesh solid and almost free from seeds. Pkt., 10c; 1/2 oz., $35 \mathrm{c} ; 0 \mathrm{z} ., 60 \mathrm{c}$.

\section{NEW TOMATO- "DINAH" \\ "A MONEY MAKER"}

In offering this novelty we believe that we are contributing a variety which will make a name for itself as a most wonderful producer. The immense fruits come in clusters and are destined to become popular with market gardeners. The cluster here illustrated weighed $4 \frac{1}{2}$ lbs., grown by Mr. Stickler, two miles west of New Albany, Ind. Trial packet, 25 seeds, postpaid, $25 \mathrm{c}$.

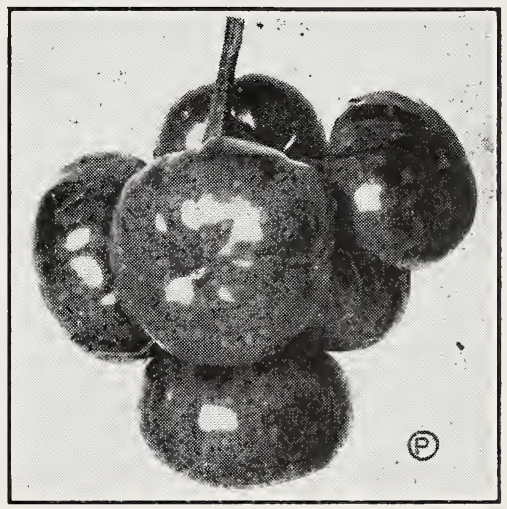

\section{TOMATOES-YELLOW FRUITED}

GOLDEN QUEEN-For those who prefer yellow-fruited tomatoes on account of their flavor we offer this main crop variety. Pkt., 10c; $1 / 2$ oz., $30 \mathrm{c}$.

GOLDEN DWARF CHAMPION-An immense yielder of fine quality. Fruits round with bright yellow skin. Bush-like, vigorous growth. Pkt., $10 \mathrm{c} ; 1 / 2$ oz., $40 \mathrm{c}$.

YELLOW PEAR PRESERVING-This is a small-fruited sort. Very productive. Pkt., $10 \mathrm{c} ; 1 / 2$ oz., $30 \mathrm{c}$.

\section{TURNIPS}

PURPLE TOP STRAP LEAF-Surpassed in earliness only by the Milan. Roots flat and 4 to 6 inches in diameter. Oz., $10 \mathrm{c} ; 1 / 41 \mathrm{~b} ., 25 \mathrm{c}$; lb., $60 \mathrm{c}$.

EXTRA EARIY PURPLE MILAN-Being the earliest Turnip in cultivation, this variety is well adapted for early. forcing. Oz., $10 \mathrm{c} ; 1 / 4 \mathrm{lb}$., $30 \mathrm{c} ; \mathrm{lb} ., \$ 1.00$.

PURPLE TOP GLOBE-Also known as Red Top White Globe. Flesh is firm, crisp and mild. Roots measure six inches in diameter. Oz., 10c; $\therefore$ b.. 250 i.., .1

SEVEN TOP - This variety produces no edible roots and is grown only for the large and tender leaves used for greens. Oz., 10c; 1/4 1b., 25c; lb., $75 \mathrm{c}$.

\section{RUTABAGA}

IMPROVED PURPLE TOP YELLOW-Flesh, rich yellow, fine-grained and sweet. Splendid for Winter storing. Oz., $15 \mathrm{c} ; 1 / 41 \mathrm{~b} ., 30 \mathrm{c} ; 1 / 2 \mathrm{lb}$., $45 \mathrm{c} ; 1 \mathrm{~b} ., 65 \mathrm{c}$. 


\section{FIELD SEEDS}

\section{ALFALFA AND CLOVERS}

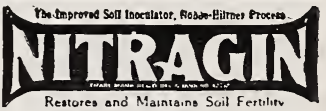

ALFALFA-This legume will thrive on well drained soil which has been thoroughly prepared by deep plowing and the application of ground limestone. Resembles clover in feeding value and habit of growth, but withstands drouth much better on account of the deep root system. May be planted either in the Spring or early Fall at the rate of 15 to 25 pounds per acre.

SWEET CLOVER WHITE BLOSSOM-A biennial used as bee food, pasture, hay and ensilage.

CRIMSON CLOVER-Highly prized as a green manure and cover crop. Sow in August or September.

MAMMOTH OR SAPLING CLOVER-Grows much taller than medium red clover with heavier, leafy stalks. and blooms about three weeks later.

ALSIKE CLOVER-Endures both cold and heat better than red Clover. Matures about the same time as Timothy and is often combined with that grass for meadows. Sow 8 to 12 pounds per acre.

RED CLOVER MEDIUM-This is our common red Clover.

WHITE DUTCH CLOVER-Valuable in permanent pastures. Much used in lawns. Growth is too short for hay.

\section{FIELD CORN}

REID'S YELLOW DENT-This is the most satisfactory vellow corn for Kentucky and Southern Indiana. Ears 9 to 10 inches long with 18 to 24 rows of narrow, deep grain. Small cob.

JOHNSON COUNTY WHITE-A large-eared variety used extensively for ensilage. Ears 9 to 11 inches in length. Grains deep and rough.

BOONE COUNTY WHITE-Very similar to Johnson County, however, the large tapering ears are smoother.

HICKORY KING-The largest grains and the smallest cob of any white corn. Splendid for milling and makes delicious roasting ears when gathered in the milk stage.

EARLY NORTHERN FIELD-This early variety of white corn in extensively used by market gardeners as it fills the barrel and brings the high prices which go to those first on the market.

\section{ASK FOR PRICES}

\section{SOY BEANS}

HOLLYBROOK-Ten days to two weeks earlier than Mammoth Yellow. Makes plenty of pods as well as forage. Seed should be inoculated with NITRAGIN.

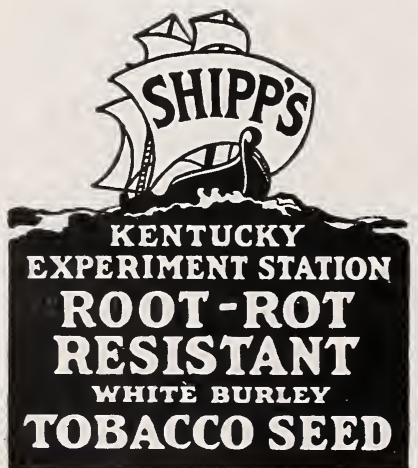

\section{T O B A C C O S E E D}

ROOT ROT RESISTANT

Stand-Up White Burley

When it comes to producing a good Tobacco crop-"the seed is the thing."

OUNCE \$1.50 POSTPAID 


\section{ENSILAGE CORN}

SOUTHERN PROLIFIC-A very dependable variety for filling silos. Produces leafy stalks with several well filled ears.

EUREKA-This corn is a selection from Southern Prolific, originated in Virginia with a view to increased size of ears and greater foliage.

COW PEAS

WHIPPOORWILI-The most popular of all varieties. Makes a hay, rich in food value and is a soil improver of great merit.

BRABHAM OR IITTLE WHIP-Almost identical in habit of growth with Whippoorwill, but the seeds are much smaller, hence less seed is required to sow an acre than of the larger varieties.

NEW ERA-Of upright, bushy growth with bluish seeds. Earlier than Whippoorwill and rapidly becoming popular in this section.

\section{ASK FOR PRICES}

\section{MILLET}

TENNESSEE CUITIVATED-Valuable on account of the quick yield of forage. Greatly relished by stock if cut when in bloom. Is ready to cut in six to eight weeks.

WESTERN-Growth is not as rank and coarse as the cultivated millet.

\section{BUCKWHEAT}

Planted during July or August, Buckwheat makes a valuable crop for bee pasture or for turning under. Sow one bushel to the acre.

\section{TIMOTHY}

Of easiest culture and the most valuable hay grass. Resists heat and cold. As it is rather hard on the soil, it should be planted with clover or followed by a generous application of manure.

\section{RED TOP}

Especially suited for pasture on low, wet soil. Stock do not relish Red Top hay as they do Timothy.

\section{KENTUCKY BLUE GRASS}

The most valuable of all pasture grasses. Rather slow in making a stand, it should be grazed lightly for the first two years. Sow 2 bushels to the acre.

\section{ASK FOR SAMPLE AND PRICES \\ CYCLONE BROADCAST SEED SOWER}

THE CYCLONE will sow practically all kinds of seeds that are sown broadcast, such as clovers, grasses, wheat, oats, rye, millet, turnips, etc., and the flow of seeds can be regulated so as to sow just the quantity you want to sow to the acre A boy can sow more acres a day than four men can sow by hand, and do it better, the seeds being more evenly distributed than is possible by hand. Don't wait till a wet spell catches you with your sowing unfinished to make you realize that if you only had a seeder you could have finished be-

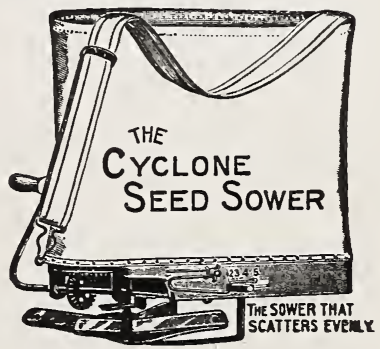
fore the rain. 


\section{FLOWER SEEDS StimUplanT Wonder Garden}

AGERATUM-The compact little bushes 9 to 12 inclses tall are well covered with feathery flowers. Suitable for bed or border.

TOM THUMB BLUE-The most popular variety. Pkt., $10 \mathrm{c} ; \mathrm{r} / 4 \mathrm{oz} ., 30 \mathrm{c}$. TOM THUMB WHITE-A profuse bloomer. Pkt., $10 \mathrm{c} ; 1 / 4 \mathrm{oz} ., 30 \mathrm{c}$.

ALYSSUM - An annual of quick growth, blocming the entire season, most useful as an edging plant, also desirable for hanging baskets.

SWEET ALYSSUM (Maritimum)-Pure white. Pkt., 10c; $1 / 2$ oz., $25 \mathrm{c}$.

LILAC QUEEN-Soft lilac flowers. Pkt., 10c; $1 / 2$ oz., $40 \mathrm{c}$.

LITTLE GEM-Very dwarf spreading habit. Pkt., 10c; 1/2 oz., 40c.

AMARANTHUS-Due to its tall growth, is useful for background effect. Do not require rich ground. Sow indoors in February and transplant in May. Sow outdoors when the maples are in leaf.

SPLENDENS (Joseph's Coat) -3 to 5 feet tall. Variegated. Pkt., $10 \mathrm{c}$.

AQUILEGIA (Columbine)-These perennial flowers range in color from pure white and yellow to deep blue, rarely blooming the first year from seed.

LONG-SPURRED HYBRIDS-Blooms in June. Pkt., 15c.

ASTERS (See inside back cover)-Seed may be sown in open seed-bed when the first trees are in leaf but better results may be obtained by planting in a well prepared flat under glass. When the young plants are set out in May, a second sowing may be made for late bloom. Ask for leaflet "How to Grow the Finest Asters."

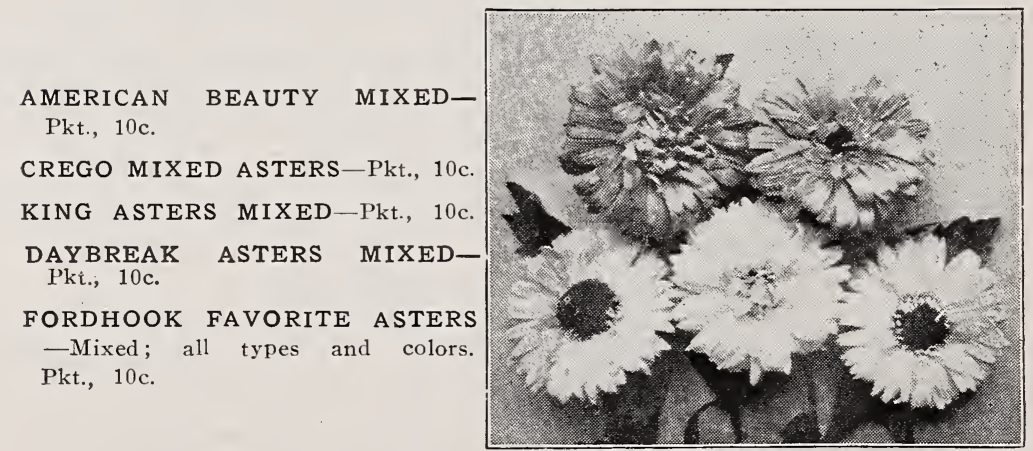

BALSAM (Ladyslipper)-This old favorite bears a profusion of double Camelia-like flowers in a wonderful range of colors from white through shining scarlet to royal purple. Sow in the open the latter part of April in rich warm soil. Water freely in summer.

DEFIANCE MIXED-A well balanced mixture. Pkt., 10c; $1 / 4$ oz., $30 \mathrm{c}$.

BALSAM APPLE (Momordica)-An interesting annual climber with creamy flowers followed by small fruits about the size of a lemon.

BALSAMINA - Sow indoors during March. Pkt., 10c.

CHARANTIA (Balsam Pear) - A rapid grower. Pkt., 10c.

CALENDULA (Scotch Marigold)-Excellent for korders or beds. Makes splendid cut flowers. Sow early in spring and transplant.

ORANGE KING-Double flowers of rich bright orange. Pkt., 10c; 1/2 oz., 35c. LEMON QUEEN-Rich lemon yellow, free bloomer. Pkt., 10c; 1/2 oz., $35 \mathrm{c}$. ROYAL "TRIANON"-Sulphur yellow, brown center with mahogany tipped petals. An odd and pleasing combination. Pkt., $10 \mathrm{c} ; 1 / 2$ oz., $30 \mathrm{c}$. DOUBLE MIXED CALENDULA-Pkt., 10c; 1/2 oz., 20c. 
CALLIOPSIS-Fine for annual borders or cut flowers. Sow seed when the maples are in leaf. Plant in sunny place, thin to 10 inches apart in the row. Of easy culture and long blooming period.

TALL MIXED-Large and small-flowering varieties. Pkt., 10c; 1/4 oz., $25 \mathrm{c}$.

CAMPANULA (Bellflower)-For rock-gardens, the perennial border or for cut flowers.

SINGLE MIXED-White, pink, rose, blue and purple shades. Pkt., 10c.

DOUBLE MIXED-Double flowers of various shades. Pkt., $10 \mathrm{c}$.

CANARY BIRD FLOWER-A useful climber for porch boxes or hanging baskets. Excellent for trellis work. Pkt., $15 \mathrm{c}$.

CANDYTUFT-Sow early in the spring, where the plants are to remain. Splendid for edging or as cut flowers. 12 inches high.

UMBELLATA MIXED-White, lilac and crimson shades. Pkt., 10c; 1/4 oz., $25 \mathrm{c}$.

CARDINAL CLIMBER-10 to 20 feet. The bright red flowers almost cover the foliage from top to bottom. Seed. should be soaked overnight in warm water before planting. Pkt., $15 \mathrm{c}$.

CELOSIA (Plumosa) MIXED-Yellow, crimson and other shades. Pkt., 10c.

COCKSCOMB MIXED-Dwarf varieties in the following shades: Pink, yellow, scarlet and crimson. Fine for cutting. Pkt., 10c.

CENTAUREA or CORNFLOWER-Sow outdoors in April, allow plenty of space and water plants freely. Bloom in eight weeks from seed and continue till frost. DOUBLE MIXED-Attractive double flowers in many shades. Pkt., 10c; I/4 oz., 30c.

CINERARIA-A desirable house plant of bright colors. Pkt., 35c.

CLARKIA-This delightful flower blooms from July till October. Sow seed early in the spring in beds or borders. The buds should be cut and placed in water to open.

FINEST DOUBLE MIXED-Rosy-purple, salmon and white. Pkt., 10c.

CLEMATIS-A most popular perennial climber for porches. Pkt., $15 \mathrm{c}$.

CLEOME (Spider Plant)-A most interesting plant, useful as a background for other flowers. 3 to 4 feet tall. Quick growth.

GIANT ROSE-Flowers delicate rose. Of easy culture. Pkt., 10c.

GIANT WHITE-Large, pure white heads. Fine for bees. Pkt., 10c.

COLEUS-Most useful as a decorative border plant. Excellent for porch boxes or an indoor pot plant. Sow the seed in fine soil in hot bed or a seed box placed in a sunny window, transplant to permanent location when the nights are warm. Mixed, pkt., $15 \mathrm{c}$.

COSMOS-This excellent autumn flower is valuable as a background and for its cut flowers. Start indoors in March.

EARLY FLOWERING MIXED-Crimson, rose and white. Pkt., 10c; 1/2 oz., 45c. LATE FLOWERING MIXED-All giant shades mixed. Pkt., $10 \mathrm{c}$; $1 / 2$ oz., $45 \mathrm{c}$. DOUBLE CRESTED MIXED-Full double centers. Three colors. Pkt. 10c.

CYPRESS VINE-This graceful climber is much used for trellis-work. The fern-like foliage is dotted: with star shaped flowers.

SCARLET-Vivid scarlet flowers. A profuse bloomer. Pkt., 10c.

WHITE-Rich green foliage with paper-white ffowers. Pkt., 10c.

DAHLIA SEED (Ask for price list of Dahlia Tubers)-Dahlias are easily grown from seed and by planting early, blooms may be had the first year. All the new varieties are produced in this way. We list seed from seven distinct types. All seed supplied by W. Atlee Burpee.

DECORATIVE MIXED-Many colors. Pkt., $15 \mathrm{c}$.

LARGE FLOWERED DOUBLE-A wonderful assortment. Pkt., 15c.

POMPON-Small, ball-shaped blossoms in all colors. Pkt., $15 \mathrm{c}$.

CACTUS FLOWERED-Petals curled and twisted. Pkt., $25 \mathrm{c}$.

PEONY FLOWERED-A well known and popular class. Pkt., 15c.

COLLARETTE-Striking combinations of color. Pkt., 10c.

SUPERB SINGLE-Immense petals. Great range of colors. Pkt,, 10c. 
SHASTA DAISY-Originated by Luther Burbank, this immense daisy is startling in size. A hardy perennial plant. Pkt., $10 \mathrm{c}$.

BLUE-EYED AFRICAN DAISY (Arctotis grandis)-The immense flowers have a blue eye and silvery white petals. Pkt., 10c.

DELPHINIUM (Perennial Larkspur)-No flower garden is complete without the charming blue flower. Seel may be sown from April till early August in well prepared seed-bed, shading the tender plants from hot sun. Avoid too much water. FORMOSUM-Rich deep blue flowers. Pkt., $20 \mathrm{c}$.

BELLADONNA SEEDLINGS-Large blooms of clear sky blue. Pkt., $15 \mathrm{c}$.

CHOICE MIXED-Colors range from white to purple. Pkt., $10 \mathrm{c}$.

DIANTHUS - This delightful flower thrives in rich soil. Sow seed during April in open ground. These China Pinks will bloom from early summer till frost. Height, 12 inches.

DOUBLE MIXED-Good for beds or cutting. Pkt., 10c.

FORDHOOK FAVORITES-Mixture of all types. Pkt., $10 \mathrm{c}$.

DIGITALIS (Foxglove)-A fine border perennial. Pkt., 10c.

DOLICHOS (Hyacinth Bean)-A popular climbing flower. Fine for fences or the porch. Height, 10 feet. Sow in May.

DAYLIGHT-White flowers followed. by white seed pods. Pkt., 10c; oz., $25 \mathrm{c}$.

DARKNESS-Flowers reddish maroon, pods purple. Pkt., 10c; oz., 25c.

ESCHOLTZIA (California Poppy)-Sow seed in April. This is a splendid flower for mass effect. Bloom till frost.

SUNSET MIXTURE-White, orange, scarlet and other colors. Pkt., 10c; r/4 oz., $20 \mathrm{c}$.

EVERLASTINGS (Straw Flower)-Mixture of many varieties. Pkt., 10c.

FEVERFEW-An old garden favorite. Fine for borders. Pkt., 10c.

FORGET-ME-NOT-Dwarf, free-flowering blue. Pkt., 10c.

FOUR O'CLOCK-The flowers open about four o'clock in the afternoon, forming a bright mass of color. Sow thinly in a row after the danger of frost is passed. TALL MIXED-Height, $2 \frac{1}{2}$ feet. All colors. Pkt., 10c; oz., 25c.

DWARF MIXED-Yellow, deep red and variegated. 18 inches. Pkt., 10c., oz., 35c.

GAILLARDIA (Blanket Flower)-This annual deserves popularity both as a cut flower and for massing in borders. Sow in open ground early and thin plants to stand a foot apart.

DOUBLE MIXED-Shades of yellow, brown, bronze and maroon. Pkt., $10 \mathrm{c}$.

BLANKET FLOWER (Perennial)-Pkt., 10c; 1/4 oz., $45 \mathrm{c}$.

GOLD DUST (Alyssum Saxatile)-This is one of the best, if not the best edging plant for borders and walks. In early spring the very dwarf plants are literally covered with a mass of yellow flowers. Seed should be sown in August if wanted for spring. Sunny, well drained locations are best. Pkt., 10c; $1 / 4$ oz., $30 \mathrm{c}$.

GOURDS-Old fashioned gardens were never complete without one or more varieties of this rapid climber on trellis or fence. Seed may be planted in the open ground in April, although several weeks may be gained by planting indoors and later transplanting.

SPOON-Fruits, 4 to 5 inches long with slender necks. Pkt., 10c.

NEST EGG-When dried the fruits may be used as nest eggs. Pkt., $10 \mathrm{c}$.

DIPPER-A well known variety with long, slender neck. Pkt., $10 \mathrm{c}$.

DISHCLOTH-The fruits may be allowed to ripen, the skin removed and the fibrous interior used as a sponge. Pkt., $10 \mathrm{c}$.

SUGAR TROUGH-The dried shell may be used as an ornament or adapted to many useful purposes. Pkt., $10 \mathrm{c}$.

FINE MIXED GOURDS-An interesting mixture. Pkt., 10c.

GYPSOPHILA (Baby's Breath)-This perennial bears myriads of tiny white flowers, useful in making bouquets. Pkt., $10 \mathrm{c}$.

HELICHRYSUM (Strawflower)-Bright color mixture. Pkt., 10c; 1/4 oz., $30 \mathrm{c.}$ 
HOLLYHOCK-This old favorite again comes into deserved popularity. Seed may

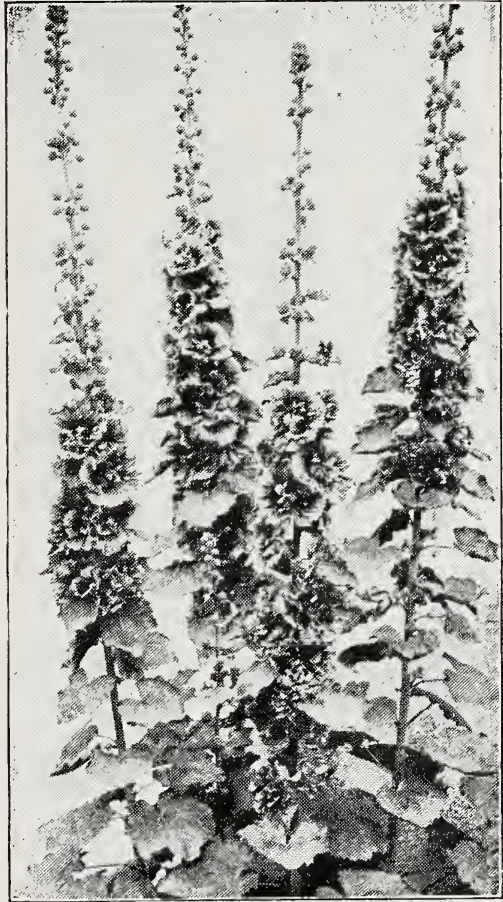
be sown in open ground from early spring until the first of August. Perennial 6 to 8 feet.

DOUBLE MIXED-All the best colors and shades. Pkt., 10c.

SINGLE MIXED-Large blooms and sturdy' growth. Pkt., 10c.

ALLEGHENY-Double flowers, fringed petals. Pkt., 10c.

HUMULUS (Japanese Hop)-A rapid climber, thrifty grower which is not subject to injury by insects. 20 to 30 feet. Pkt., 10c.

KOCHIA (Burning Bush)-An ornamental annual forming a perfect globe-shaped bush. Sow seed in early spring.

TRICOPHYLLA-In autumn the plant turns to scarlet. Pkt., $10 \mathrm{c}$.

GIANT CHRISTMAS-Turns to crimson-purple in fall. Pkt., $10 \mathrm{c}$.

LANTANA-Bloom the first year from seed and make a splendid showing as potted plant or in porch-boxes.

MIXED-Pkt., $10 \mathrm{c}$.

LARKSPUR-Useful as a cutflower, also makes a splendid annual for beds. Thin the young plants to stand 8 to 10 inches apart. The flowers are borne in spikes on tall, stiff stems. The bright colors are indeed pleasing.

MIXED TALL DOUBLE-Blue, white, pink, purple and rose. Pkt., $10 \mathrm{c} ; \mathrm{r} / 4$ oz., $25 \mathrm{c}$.

LOBELIA-Perennial 8 to 12 inches. Pkt., $15 \mathrm{c}$.

MARIGOLD-Tall African. 21/2 feet. Sow in drills when danger of frost is past. Bloom from July till frost.

ORANGE BALL-Large double flowers of rich orange. Pkt., 10c.

LEMON BALL-Very large flowers of canary yellow. Pkt., $10 \mathrm{c}$.

AFRICAN DOUBLE MIXED-The above colors in mixture. Pkt., 10c.

MIGNONETTE-This fragrant flower is easily grown from seed which should be planted when the maples are in leaf. For best results, plant in light sandy soil.

MIXED-A selection of the finest types. Pkt., 10c.

MOONFLOWER-The dense green foliage of this annual climber often reaches a hight of 20 to 30 feet in $a_{1}$ single season. Seed may be started indoors in March or planted in the open when the trees are in leaf.

WHITE-SEEDED-Immense white flowers. Pkt., 10c; $1 / 2$ oz., 35c.

GIANT PINK HYBRID-Beautiful new color. Pkt., 10c; $1 / 2$ oz., 35c.

SKY-BLUE-Blooms in September. 15 feet. Pkt., $15 \mathrm{c}$; $1 / 2$ oz., $60 \mathrm{c}$.

MORNING GLORY-Sow seed when the trees are in leaf. 15 feet.

IMPERIAL JAPANESE MIXED-Flowers of delicate shade. Pkt., $10 \mathrm{c}$.

FINE MIXED-Free-flowering. All colors mixed. Pkt., $10 \mathrm{c}$.

TALL NASTURTIUM-For a wealth of color, few flowers surpass this free-flowering annual. The tall varieties may be allowed to trail on the ground, producing massive beds of color.

BUTTERFLY-Lemon-yellow flowers, blotched red. Pkt., 10c; oz., $20 \mathrm{c}$.

FORDHOOK FASHION-Blue-green foliage, red flowers. Pkt., 10c; oz., 25c; 
TWILIGHT-Delicate, salmon-colored flowers. Pkt., 10c; oz., 20c. MIDNIGHT-Brownish red flowers, velvety texture. Pkt., 10c; oz., $20 \mathrm{c}$.

TALL MIXED-A blend of finest colors. Pkt., 10c; oz., 15c.

DWARF NASTURTIUMS-These low-growing plants produce flowers of the best quality in shades covering a wide range.

AURORA-Chrome-yellow flowers, veined with carmine. Pkt., 10c.

CLOTH OF GOLD-Yellow foliage, flowers scarlet. Pkt., 10c; oz., 20c.

EMPRESS OF INDIA-Salmon-scarlet flowers. Pkt., 10c; oz., 25c.

GOLDEN MIDNIGHT-Dark red with golden foliage. Pkt., 10c., oz., 20c.

DWARF MIXED-Choice, large-flowered varieties. Pkt., 10c;oz., 15c.

NICOTIANA (Flowering Tobacco)-Fragrant blossoms ranging in color from white to bright red. Sow early under glass and transplant in May. Height, 3 feet. NEW HYBRIDS-Fine for use as background. Pkt., 10c.

NIGELLA (Love-in-a-Mist)-Double, blue flowers, well adapted to mass planting. Good as a cut flower. Pkt., 10c.

PANSIES-If you wish to grow the largest and finest types of this flower, start with the careful selection of seed. Plant indoors during February or March and transplant when large enough to be handled. If flowers are wanted for early spring, the seed should: be sown in August.

GIANT FANCY BURPEE BLEND-Contains the largest and most beautiful of all blotched pansies. Pkt., 25c.

MASTODON-Immense flowers, thick waved petals. Pkt., 25c.

TRIMARDEAU-Large flowers, mixed colors. Pkt., 10c.

EXTRA FINE MIXED BEDDING-Profuse bloomer. Pkt,, 10c.

CASSIER'S GIANT-3 to 5 blotched petals, large. Pkt., $15 \mathrm{c}$.

BUGNOT-Differs from the Cassier's in that the blotches are not defined but blend into the margin. Pkt., $15 \mathrm{c}$.

PARIS IMPROVED BLOTCHED-This is a profuse bloomer with thick, well blotched petals. Pkt., $15 \mathrm{c}$.

PAPAVER ORIENTALE (Oriental Poppy)-Immense red flowers. Seed of this perennial may be sown in the early spring. The plants are dormant during July and August, reappearing when cool weather sets in. When this new growth appears, transplant to permanent location. Pkt., 10c.

PERENNIAL PEAS (Lathryus)-Continuous bloomer. Mixed pkt., 10c.

PERENNIAL FLAX-Rich, blue flowers. 15 inches. Pkt., 10c.

PETUNIA-Started in boxes or pots, this annual will bloom from June till November. Requiring little or no care, petunias present a gorgeous array of color in beds or boxes. The seed of large and double-flowered varieties are produced by hand polinizing and hence are quite expensive. These varieties should be started in boxes of well prepared soil and placed in a sunny window. When the plants are large enough, they should be transplanted to small pots and when taken to permanent location, should stand 12 inches apart. Do not discard small plants as they often produce the finest blooms. Use rich soil.

BEDDING MIXED HYBRIDS-Fine for porch boxes. Pkt., 10c.

BURPEE'S DEFIANCE-Enormous size, varied colors. Pkt., 35c.

BALCONY PETUNIAS-Desirable for the rock garden, porch or window boxes. Seed may be sown outdoors in April or earlier under glass. We offer three colors. One packet of each will be mailed postpaid for $25 \mathrm{c}$.

BALCONY WHITE-Very large flowers. Pkt., 15c.

BALCONY ROSE-Rose flowers with white throat. Pkt., 15c.

BALCONY BLUE-Purplish blue turning to purplish red. Pkt., 15c.

PHLOX-One of the best annuals for use where a mass of vivid color is desired. The Fordhook strain of seed offered by us cannot be surpassed. Sow the seed as early in the spring as the ground can be worked into good condition. Try a border of Phlox in your garden this year.

FORDHOOK FINEST MIXED-Apricot, crimson, violet and white. Pkt., $10 \mathrm{c}$.

POPPIES PEONY-FLOWERED ANNUAL-The double flowers are of easiest culture. Many colors. Pkt., 10c.

IMPROVED SHIRLEY-Rose and salmon shades, double. Pkt., 10c. In sowing poppies, barely cover the seed. They will not stand transplanting. 
PORTULACA (Moss Rose)-The moss-like leaves of this annual are fairly hidden with the brightest flowers of yellow, scarlet, orange and white. Thrives in sun-baked locations.

SINGLE MIXED-Complete blend of all shades. Pkt., 10c.

DOUBLE MIXED-Unsurpassed for brilliancy. Pkt., 10c.

PYRETHRUM-This hardy perennial has immense, daisy-like flowers in white, pink and rose. Pkt., $10 \mathrm{c}$.

SALPIGLOSIS (Velvet Flower)-The bloom is somewhat like the Petunia in appearance. Good cutflower. Barely cover the seed. Colors are violet, scarlet and yellow with intermediate shades. Mixed pkt., 10c.

SALVIA (Scarlet Sage)-Sow seed under glass in March. Transplant seedlings to small pots and keep indoors until danger of frost is past.

SPLENDENS - 3 to 4 feet high. Impressive scarlet. Pkt., 10c. ZURICH-18 inches. Neatly rounded plants. Pkt., $15 \mathrm{c}$.

FARINACEA-This is a light blue sage. Pkt., $10 \mathrm{c}$.

SCABIOSA (Mourning Bride)-The fully double flowers borne on long stiff stems, together with good keeping quality makes this a most popular garden annual. The colors range from white and pale yellow through pink and rose to deep purple.

TALL LARGE-FLOWERED DOUBLE MIXED-All colors. Pkt., 10c.

SCHIZANTHUS (Poor Man's Orchid)-Sow seed: in permanent location, pinching back young plants. Pkt., 10c.

SENSITIVE PLANT (Mimosa pudica)-When touched, the leaves curl and the stems droop. An interesting plant. Pkt., $10 \mathrm{c}$.

SMILAX-An excellent window vine. Pkt., $10 \mathrm{c}$.

SHAMROCK (Irish)-Pkt., 10c.

SNAPDRAGON (Antirrhinum)-This annual, easily grown from seed, may be sown indoors in March or outside during April. Blooms from June till frost. Will stand some shade.

GIANT MIXED-Tall spikes, all colors, 30 inches. Pkt., $15 \mathrm{c}$.

HALF-DWARF SNAPDRAGON-These are compact plants, 15 inches tall and do not require staking. Blooms unsurpassed.

HALF-DWARF SHELL PINK-Large flowers. Pkt., 10c.

HALF-DWARF FIREBRAND-Dark crimson. Pkt., 10c.

HALF-DWARF BRILLIANT ROSE-Large flowers. Pkt., $10 \mathrm{c}$

HALF-DWARF VELVET GEM-Blackish maroon. Pkt., $10 \mathrm{c}$.

HALF-DWARF GOLDEN OUEEN-Lemon yellow. Pkt., $10 \mathrm{c}$.

HALF-DWARF FANCY MIXED-All colors, Pkt., 10c.

DWARF SNAPDRAGON-Blend of all colors. 8 inches. Pkt., $10 \mathrm{c}$.

STATICE-Sow seed under glass in February and transplant to open ground when the maples are in leaf.

SINUATA BLUE-Profuse bloomer. Graceful stems. Pkt., 10c.

SINUATA ROSE-Light rose flowers. 18 inches. Pkt., 10c.

STOCKS-The principal charm of this flower is in the fragrance of its soft-colored flowers which are borne on tall stems. A valuable plant for beds and borders. A good cut-flower and excellent for designs. The colors are white, yellow, pink, crimson and violet.

LARGE-FLOWERED MIXED DWARF-Ten weeks. Pkt., 10c.

MAMMOTH BEAUTY OF NICE MIXED-24 inches. Pkt., $10 \mathrm{c}$.

SUNFLOWER-Many-flowered double, 5 feet tall. Pkt., 10c; $1 / 2$ oz., 30c.

SWEET WILliAM, SINGLE MIXED (Perennial)-Sow April to June. Pkt. 10c.

THUNBERGIA (Black-Eyed Susan)-This vine is used for boxes, hanging baskets and low trellisses or allowed to trail on the ground. Blooms June to October. Pkt., $15 \mathrm{c}$.

VERBENA-Bloom June to October. Easily grown and are very desirable for beds, porch boxes and window boxes. Plant indoors during March and set out in May. FORDHOOK FAMOUS MIXTURE-All colors. Pkt., $10 \mathrm{c}$.

VINCA-Finest Mixed. Pkt., 10c.

WALLFLOWER-Sow from early spring till August. Will do well indoors. Fine Double Mixed. Pkt., 20c. 


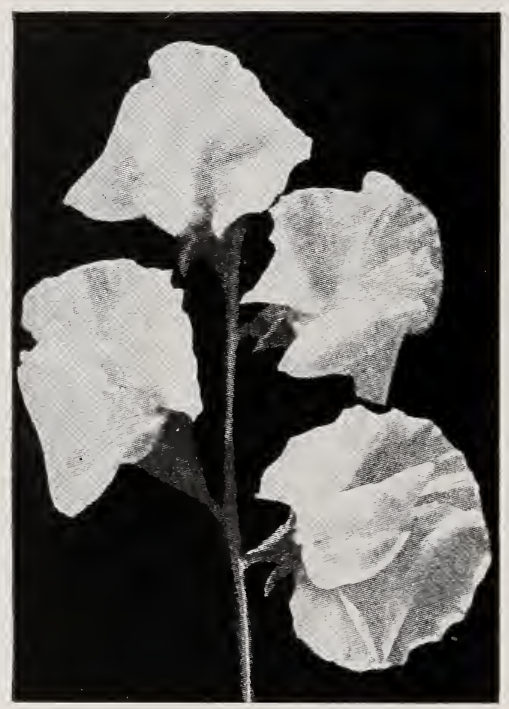

SWEET PEAS-Should be planted in a well drained sunny location. If the ground be heavy, dig trenches deeply and mix in rough stable litter or strawy manure giving a liberal dressing of bone meal at the surface. For best results, this trenching should be done some time before planting. When the ground is in good working condition, add a dressing of Acid Phosphate. You will be well repaid for planting seed in pots under glass during January or February. If planting is to be made in the open ground, sow by the middle of February if weather and soil conditions permit. Dig trench 4 inches deep and cover seed with two inches of earth. When the plants have advanced in growth, thin out to stand six inches apart and draw earth up to them. Support should be given as soon as possible to the young vines.

KING WHITE-The finest white grown. Pkt., 10c; oz., 45c.

ELEGANCE-Bluish-lilac blush. Pkt., $10 \mathrm{c} ;$ oz. $35 \mathrm{c}$.

IMPROVED MARGARET ATLEECream pink. Pkt., 10c; oz., 45c.

HERCULES-Deep rose pink. Enormous. Pkt., 10c; oz., 35c.

FIERY CROSS-Deep cherry red. Pkt., $10 \mathrm{c} ;$ oz., 35c.

THE PRESIDENT--Brightest orange scarlet. Pkt., 10c; oz., 35c.

TANGERINE-Orange colored. Superb. Pkt., 10c; oz., 60c.

KING EDWARD-Reliable deep rich crimson. Pkt., 10c; oz., 35c.

FLORENCE NIGHTINGALE-Soft clear lavender. Pkt., 10c; oz., 35c.

ROYAL PURPLE-Warm rich purple. Pkt., 10c; oz., 35c.

WARRIOR-Reddish maroon, flushed bronze. Pkt., $10 \mathrm{c}$; oz., $35 \mathrm{c}$.

MIXED SPENCER SWEET PEAS-Pkt., 10c; oz., 30c.

SWEET SULTAN-For borders or cut flowers, 24 in. Pkt., 10c.

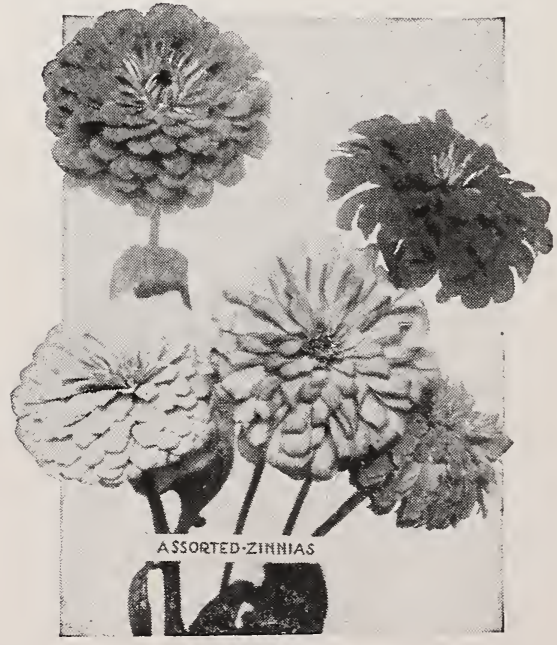

ZINNIAS
ZINNIAS-(See inside front cover for Burpee Giant Zinnias).

GIANT MAMMOTH MIXED ZINNIAS-Pkt., $10 \mathrm{c} ; 1 / 4$ oz., 35c.

NEW CACTUS FLOWERED-Pkt., $15 \mathrm{c} ; \mathrm{r} / 4 \mathrm{oz} ., 60 \mathrm{c}$.

CURLED AND CRESTED ZINNIAS-Pkt., 10c; I/4 oz., 35c.

DAHLIA FLOWERED MIXEDPkt., 15c; 1/4 oz., 60c.

PICOTEE MIXED ZINNIAS-Pkt., $15 \mathrm{c}$; $1 / 4$ oz., $50 \mathrm{c}$.

WILD FLOWER GARDEN MIXTURE-Of easily grown annuals which will produce a wealth of color and a profusion of cut flowers with a minimum of care. Seed may be sown in rows or broadcast over a well-prepared seed bed. Covered lightly or firmly pressed into the soil. Plants should be thinned to stand 6 to 10 inches apart. Pkt., $10 \mathrm{c}$; oz., 30c. 


\section{HARDY PERENNIAL PLANTS}

In answer to a popular demand for roots or clumps of hardy flowers, this department of our business has been developed and expanded to such an extent that we are now prepared to supply many standard sorts. Should you desire varieties not listed here, we solicit your inquiry, as we wish to add to this list such items as our customers desire.

As these plants are grown at some distance from our city establishment, orders may be held for a few days awaiting fresh supplies. Delays may also be occasioned by weather or seasonal conditions but it will always be our purpose to forward orders in good time for planting.

Most perennials may be planted either in spring or fall. When planted in the spring, they will bloom the first year and will continue to bloom for many seasons with very little care. In arranging borders, note height and blooming period.

\section{PRICE OF HARDY ROOTS, EXCEPT AS NOTED, EACH, 20c;} 12 OF A KIND, $\$ 2.00$.

AQUILEGIA (Columbine)-Long-spurred Hybrids, all colors, fine for border and rock garden, 2 feet. June-October.

ASTERS (Michaelmas Daisy) -5 feet. September-October.

CHRYSANTHEMUM-The development of this flower has made it possible to have beautiful life and color in the garden when the other hardy plants have passed. Red, pink, white, violet and yellow.

COREOPSIS--Excellent cut flowers in rich golden yellow, 2 feet. Blooms all summer. Illustrated on front cover.

SHASTA DAISY - A much improved hardy daisy, bearing large white flowers from early summer till late fall, 24 to 30 inches.

DELPHINIUM (Hardy Larkspur)-The greatest charm of the improved Delphiniums lies in their stateliness of growth. No other blue flower can compare with Delphinium or surpass it in usefulness. As cut flowers they are splendid. BELLADONNA-Light blue. FORMOSUM-Dark blue.

DIANTHUS BARBATUS (Sweet William)-Among the old-fashioned plants this one is certainly very popular. Their striking colors, free-blooming qualities and pleasing fragrance make them a favorite. Fine for cutting. 18 inches. Bloom all summer.

DIGITALIS (Foxglove) - A well grown plant of Foxglove is a joy. When flowering apply WIZARD manure in liquid form. 3 to 5 feet. Blooms June-July. As soon as roots are received-unpack and plant.

GAILLARDIA-This excellent cut flower blooms constantly from June till October in brilliant colors of yellow, orange and crimson. 2 feet. For a beautiful sight, arrange a vase of cut flowers of Gaillardia with Delphinium and Shasta Daisy. (See front cover).

GOLDEN GLOW (Rudbeckia) -5 feet. July-September. Good for cutting.

GYPSOPHILA (Baby Breath)-3 feet. July-August.

HOLLYHOCK (Althea)-Red, yellow and beautiful shades of pink. 5 to 6 feet. A garden is not complete without this majestic flower. DOUBLE MIXED. SINGLE MIXED.

PHLOX-For brilliance of color and delicate fragrance we can not suggest anything which will surpass Phlox. We have selected the following varieties as being the best for home gardens at popular prices. Flowering in July, the blooming period may be prolonged by cutting the past spikes.

BEACON-Bright cherry-red. Medium height. (See front cover). 
MRS. JENKINS-Very fine white, robust grower.

CHAMPS ELYSEE-Fine dark purple.

THOR-Very large trusses of dazzling pink.

ELIZABETH CAMPBELL-Brilliant salmon-pink, dark crimson eye. 30c each.

PYRETHRUM-Large daisy-like flowers of crimson, pink and white, 2 to 3 feet.

Bloom in June. When cut they last many days.

PRICES, EXCEPT AS NOTED ABOVE, EACH, 20c; 12 OF A KIND, \$2.00.

\section{COLLECTIONS OF HERBACEOUS PERENNIALS}

Front Cover Collection, one each, 6 varieties, $\$ 1.10$.

Front Cover Collection, three each, 6 varieties, $\$ 3.00$.

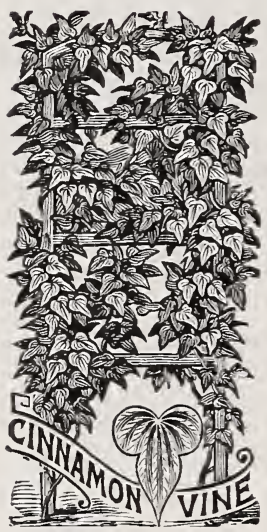

CINNAMON VINE-A rampant grower sending up shoots from a potato-like tuber, attaining a height of 10 to 30 feet. Suitable for porches and arbors where shade is desired. Tubers each, $10 \mathrm{c} ; 3$ for $25 \mathrm{c}$.

TUBEROSE, DWARF PEARL-Each, 10c; 3 for $25 \mathrm{c}$.

CALADIUM ESCULENTUM (Elephant Ear)-Good as single plants or in masses for tropical effect. Plant in warm. moist soil. Mammoth Bulbs, 30c each; medium, 20c each.

\section{CANNAS}

Plant deeply in well manured, rich soil as soon as the danger of frost is past, 18 inches apart. Cannas like plenty of moisture. Cannas have been much improved in late years and the large flowered varieties we offer are not to be confused with common "Indian Shot."

KING HUMBERT-This is a gorgeous orange scarlet flower of immense size. Foliage purplish bronze. 4 to 5 feet tall. $20 \mathrm{c}$ each; 6 for $\$ 1.00$.

FIERY CROSS-Vivid scarlet flower heads of great size, blue-green foliage. June till frost. $4 \mathrm{I} / 2$ feet. Each, $20 \mathrm{c} ; 6$ for $\$ 1.00$.

APRICOT-Large flowers of a most attractive color. Each, 25c; 6 for \$1.25.

MRS. ALFRED CONRAD-Green foliage, 4 feet tall. Large flowers of an exquisite salmon-pink. Each, 20c; 6 for $\$ 1.00$.

EUREKA-The best white canna, green foliage. $4 \frac{1}{2}$ feet. Each, $25 c$; 6 for $\$ 1.25$.

\section{GLADIOLI}

The Gladiolus easily takes first place among these flowers which are useful for cutting over a long season. By planting a succession of bulbs, flowers may be had from early summer till frost. Plant bulbs when the trees are in leaf.

EVELYN KIRTLAND-Strong spikes of coral-pink shaded deep pink on lower petals. Each, $10 \mathrm{c} ; 12$ for $\$ 1.10 ; 50$ for $\$ 3.00$.

MRS. FRANCIS KING-Light scarlet flowers of good substance. Profuse bloomer. 12 for $60 \mathrm{c} ; 50$ for $\$ 2.00$. 


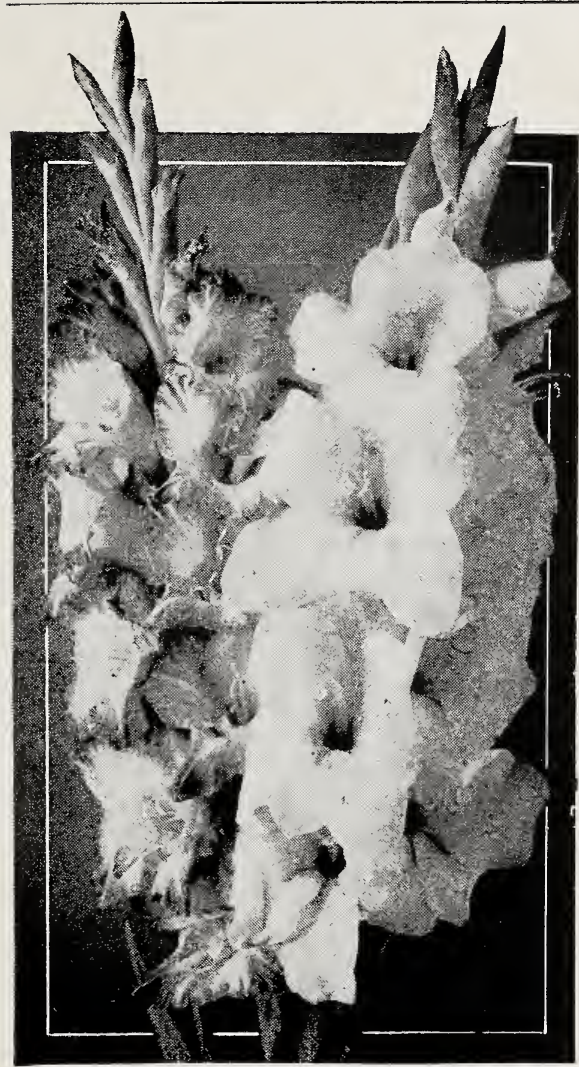

WAR-Deep blood red shaded crimson-black. 12 for $\$ 1.20$; 50 for $\$ 4.00$.

PURITY - A white gladiolus of fine substance. You will be pleased with this flower. Dozen, $75 \mathrm{c} ; 50$ for $\$ 1.75$.

AMERICA-Soft lavender pink. Splendid bloomer. 12 for $50 \mathrm{c}$; 50 for $\$ 1.75$.

CHICAGO WHITE-White with lavender markings in the throat. Each, $10 \mathrm{c} ; 12$ for $75 \mathrm{c} ; 50$ for $\$ 2.60$.

HALLEY - Delicate salmon-pink with red stripe running through lower petals. One of the earliest bloomers. Each, 10c; 12 for $75 \mathrm{c}$; 100 for $\$ 5.00$.

MRS. F. PENDLETON-A beautiful salmon-pink with dark crimson blotches in the throat. Excellent for cutting. Each, 10c: dozen, $80 \mathrm{c} ; 100$ for $\$ 5.50$.

SCHWABEN-Clear canary yellow shading to sulphur. Each, $10 \mathrm{c}$; dozen, $\$ 1.00 ; 100$ for $\$ 6.00$.

MIXED COLORS-Dozen for $60 \mathrm{c}$; 100 for $\$ 2.50$.

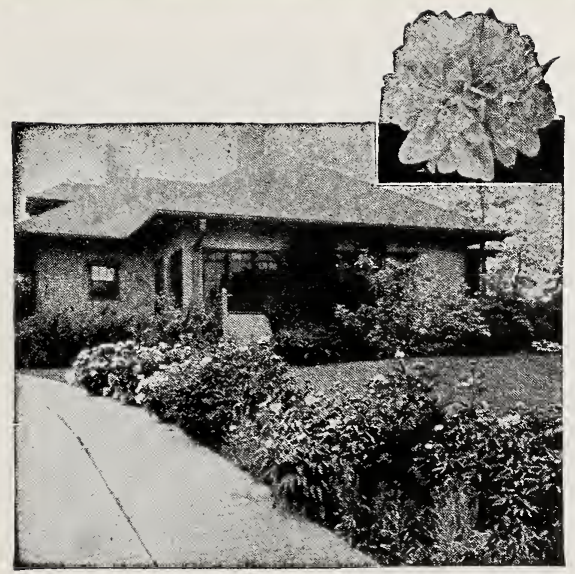

\section{PEONIES}

EDULIS SUPERBA-Large, loose flowers of deep pink. Quite fragrant. Early. Each, 45c; 3 for $\$ 1.10$.

FELIX CROUSSE-Large globular flowers of bright ruby red. The best red Peony. Each, 60c; 3 for $\$ 1.50$.

FESTIVA MAXIMA-Immense globeshaped flowers of pure white flecked with crimson. Each, 45c; 3 for $\$ 1.10$.

CROWN OF GOLD-White flowers with a crown of yellow stamens. Late blooming, fragrant. Each, 60c; 3 for $\$ 1.50$.

Peonies, when planted in the Fall, will bloom the following season. They prefer a sunny location and rich, loamy soil. 


\section{FREE GARDEN LEAFLETS}

Through the courtesy of W. ATLEE BURPEE CO., we offer the foilowing leaflets of cultural directions to our customers:

Suggestions On Seed Sowing

Summer Gardening

Hotbeds and Cold-Frames

Root Crops

Onions From Seed

Greens and Salads

How To Grow Celery

Cabbage and Cauliflower

How To Make An Asparagus Bed

Mushroom Culture

Herbs: Their Culture and Uses

How To Grow Peas

How To Grow Beans

Melons For All

How To Grow Tomatoes
Cucumbers, Squashes and Pumpkins

Insect Pests and Plant Diseases

Growing and Storing Vegetables For

Winter Use

Cover Crops and Green Manure

How To Establish A Lawn

How To Grow Sweet Peas

How To Grow The Finest Asters

How To Grow Nasturtiums

How To Grow The Largest Pansic

The Annual Flower Garden

Perennials From Seed

How To Grow Flowers In The House

How To Grow Flowers From Bulbs

Special Culture of Dahlias

Requests for special information on gardening should be sent by mail. We will gladly solve your garden problems, whenever it is possible to do so.

\section{GARDEN GUIDE}

The Gardeners' Handbook; 384 pages, over 275 illustrations.

The gem of garden literature. Over 40,000 ropies sold throughout the United States and Canada.

GARDEN GUIDE has wonderful chapters devoted to the Vegetable, Flower and Fruit Gardens, with practical layouts and planting plans. It tells you in full how to prepare and fertilize your ground, how to distinguish and get rid of insect pests. Bulbs and flowers are fully treated, the lawn, ornamental trees and shrubs, vines, water plants. How to spray; how to prune plants; how to propagate plants; how to construct hotbeds and forcing frames.

Covers every step from spading the ground to preserving the harvest.

Price, cloth bound, $\$ 1.50$, postpaid, $\$ 1.60$.

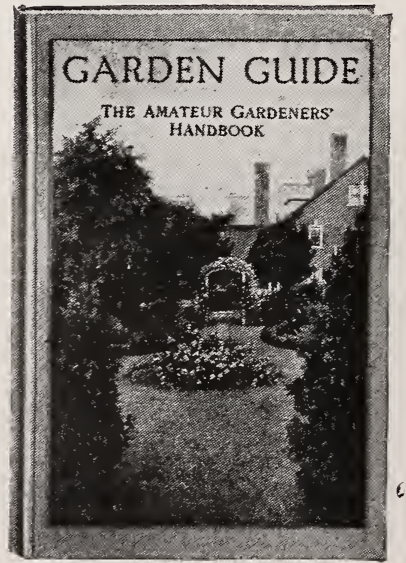




\section{A LITTLE BOOK OF ANNUALS}

For the Amateur and Professional; 116 pages, illustrated.

"Among the choicest flowers scattered over the earth are some whose lives are short. They sprout from seed, grow, flower, produce seed in their turn and then die, all within the limits of a single growing season of our gardening year. These are the Annuals."

Chapters include: The Use of Annuals, Ordering Seeds, Classes of Annuals, Seed Sowing, Transplanting, Pinching, The Hoe vs. the Hose, Watering vs. Sprinkling, Annuals and Shade, Fall Sowing and Self-sown Annuals, Annuals of Merit, Everlastings, Decorative Seed Pods, Annual Vines, etc.

Price, cloth bound, $\$ 1.50$, postpaid, $\$ 1.60$.

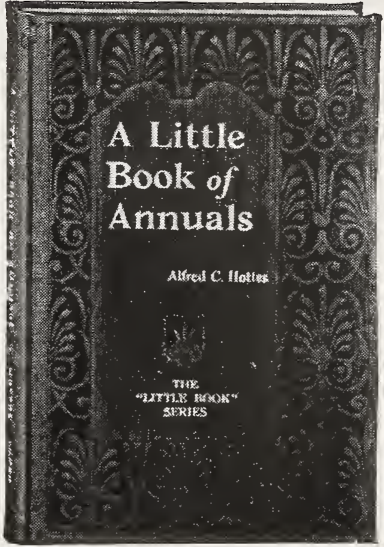

\section{A LITTLE BOOK OF PERENNIALS}

Companion Book to the Little Book of Annuals.

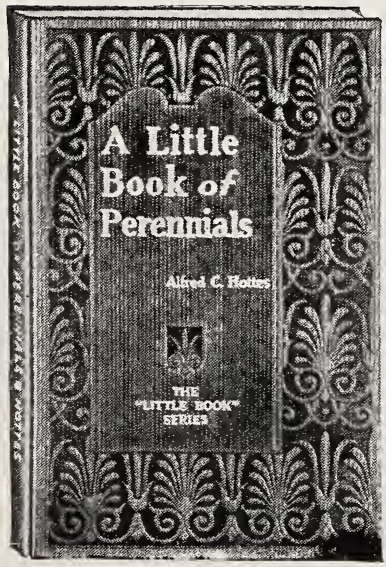

Devoted to the general principles of growing, using, selecting and propagatin $r$ perennials, followed by a number of comprehensive lists of perennials, suited for different locations and purposes. The most important and useful representatives of this popular class of garden plants- to the number of 125 separate species-are discussed individually, together with their culture and requirements.

A tabular cultural index, giving species or variety, height, color, flowering period, etc., adds to the value of the book. Profusely illustrated, interesting and instructive to both amateur and professional.

Price, cloth bound, $\$ 1.50$, postpaid, $\$ 1.60$. 


\section{THREE-PIECE GARDEN SET}

Set of three tools consists of one each, Garden Trowel, Transplanting Trowel and Hand Weeder. All made of pressed steel, handsomely finished in black baked enamel. Packed in paper carton. Shipping weight, 2 lbs. Per set, $75 \mathrm{c}$.

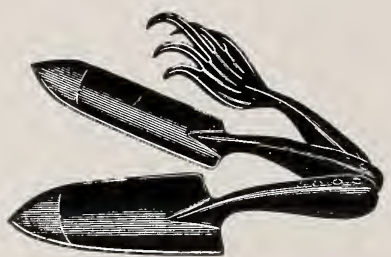

WOODEN LABELS

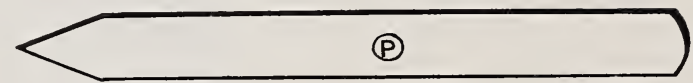

Garden Label

100

1,000

8 in., Painted

$\$ 2.25$

12 in., Painted

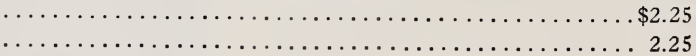

$\$ 12.00$
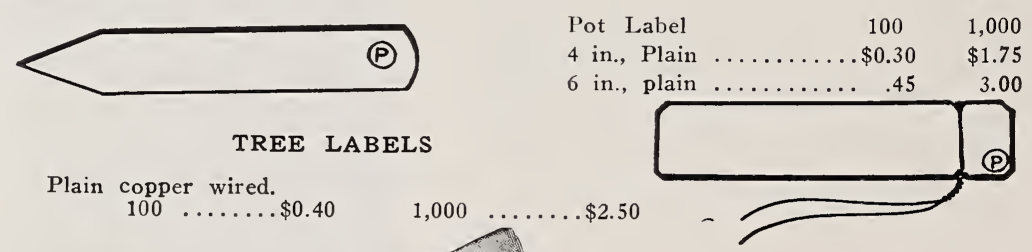

TREE LABELS

Plain copper wired.

$100 \ldots \ldots \ldots \$ 0.40$

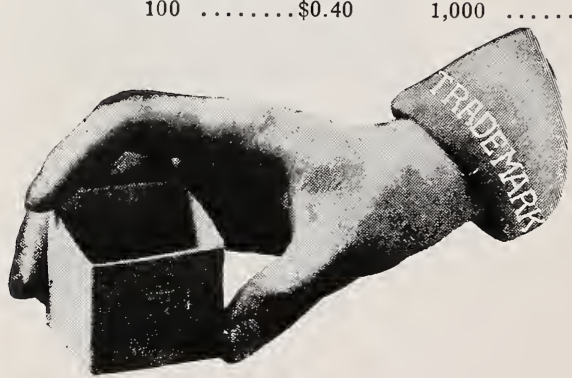

Pot Label

12.00

\section{PLANT BANDS}

To be used instead of clay pots for starting seedlings. Made of heavy waterproof paper.

\begin{tabular}{lrrrr} 
Size & \multicolumn{1}{c}{ Dimen. } & 100 & 1,000 \\
2B & $2 \times 2 \times 21 / 2 \ldots$ & $\$ 0.50$ & $\$ 4.00$ \\
3B & $3 \times 3 \times 3$ & $\ldots$ & .60 & 5.00 \\
$4 \mathrm{~B}$ & $4 \times 4 \times 3$ & $\ldots$ & .70 & 6.00
\end{tabular}

HAND WEEDER (Moe's) Each 20c.

\section{PLANT TUBS}

Davis No $3 \quad \ldots .8$ Bottom Depth Each

Davis No. $5 \ldots 10$ in. $71 / 2$ in. 9 in. 1.25

Davis No. $7 \ldots 12$ in. 9 in. 11 in. 1.60

Davis No. $9 \ldots 14$ in. 11 in. 13 in. 2.20

Davis No. $11 \ldots 16$ in. $12 \frac{1}{2}$ in. 15 in. 2.75

Handles extra at $\$ 0.30$ per pair.

All tubes made of cypress and cedar. Finished green

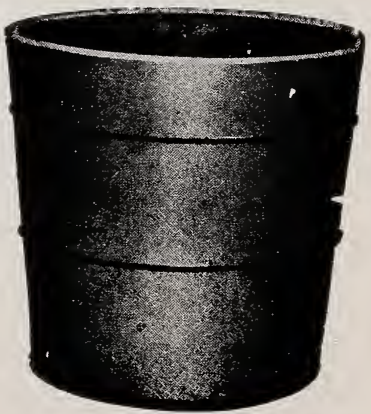


CEMETERY FLOWER VASES (Earthen) Each 25c Express or freight at customer's expense.

EARTHEN FLOWER POTS

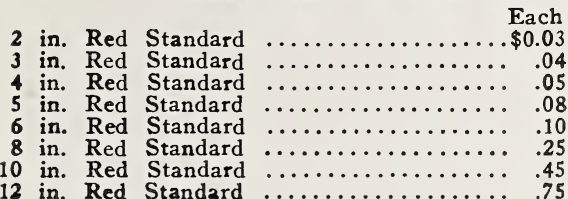

\section{BULB PANS}

6 in. Bulb and Fern Pans .........\$0.15

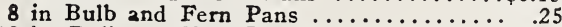

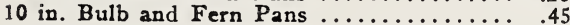

$\$ 1.50$

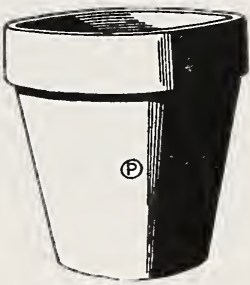

Doz.

.50

.80

1.15

5

\section{SAUCERS}

6 in. Saucers

8 in Saucers

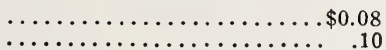

10 in. Saucers

$\cdots \cdots \cdots \cdots \cdots \cdots \cdots \cdots \cdots \cdots \cdots \cdots \cdots$

$\$ 0.75$

1.10

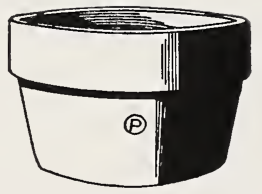

\section{NEPONSET PAPER POTS}
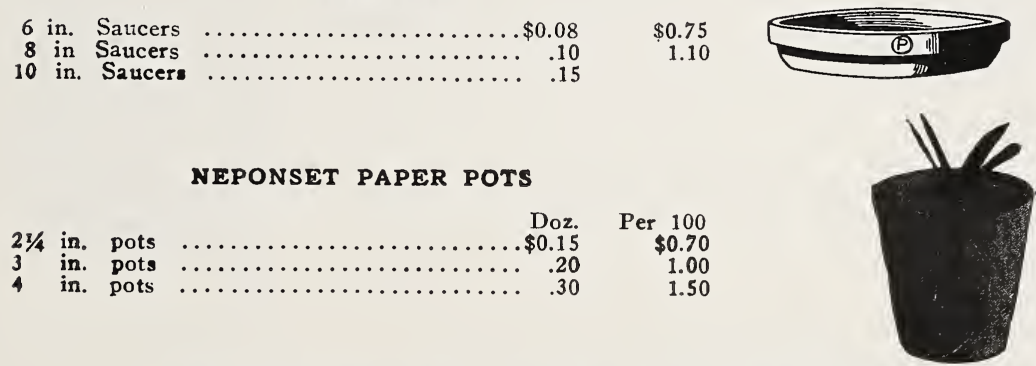

\section{FERTILIZERS FOR LAWN AND GARDEN}

LAWN AND GARDEN FERTILIZER-3-12-4. A well balanced chemical fertilizer. 5 lbs., 30c; 10 lbs., $50 \mathrm{c} ; 100$ lbs., $\$ 3.50$.

ACID PHOSPHATE 16\%-5 lbs., 30c; 10 lbs., 50c; 25 lbs., $\$ 1.00 ; 100$ lbs., $\$ 2.50$.

LAWN LIME-Sweetens the soil and promotes the growth of Blue Grass. 50 lbs., 80 c; 100 lbs., $\$ 1.50$.

BONE MEAL-Gives lawns that deep green color and is fine for incorporating with potting soil. Gives substance to the bloom of flowers. Work into soil around shrubs. 5 lbs., $40 \mathrm{c} ; 10$ lbs., $60 \mathrm{c} ; 25$ lbs., $\$ 1.50 ; 100$ lbs., $\$ 3.50$.

\section{STIM-(U)-PLANT}

StimUplanT

Makes a

Wonder Garden

\section{PLANT STIMULANT TABLET}

STIM-U-PLANT-An odorless, clean plant food in tablet form for use the year round. Will make your garden a WONDER GARDEN. May be dissolved and applied as a liquid. Fine for ferns. 30 tablets, $25 \mathrm{c}$; 100 tablets, $75 \mathrm{c} ; 1,000$ tablets, $\$ 3.50$.

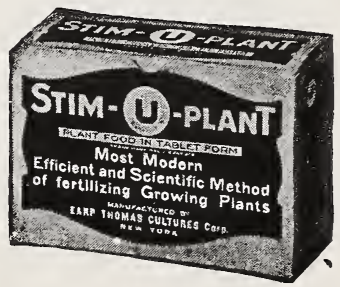




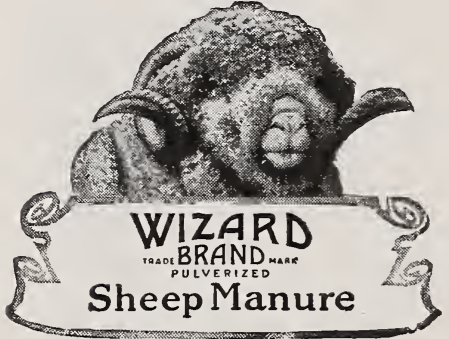

Ask for free booklet.

The finest sheep manure and nothing else. Dried, sterilized, ground to make it easy to handle. Weed seeds killed. The best fertilizer money can buy for flowers, vegetables, fruits, shrubs, vines, grass and field crops. Superior to chemical stimulants because it is a natural fertilizer supplying soil with BOTH plant food and humus. Easy to use-results sure to amateur and professional alike. Used by thousands. Try it this season and you will never plant without it.

5 lb. bag $\ldots \ldots \ldots \ldots \$ 0.30$

10 lb. bag $\ldots \ldots \ldots \ldots . .55$

25 lb. bag .......... 1.25

50 lb. bag $\ldots \ldots \ldots \ldots, 1.75$

100 lb. bag .......... 2.75

A WHOLE WAGON-LOAD IN A BAG

$2000 \mathrm{lb}$.

"Makes Good Seed Grow Better."

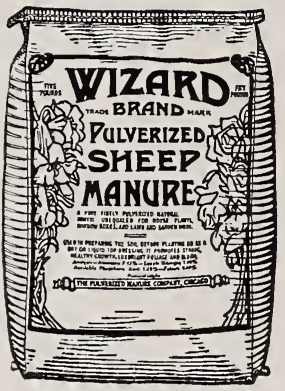

NITRATE OF SODA-Supplies nitrogen to the soil. A very active forcer. Applications should seldom exceed 300 pounds to the acre or one ounce to the square yard. May be dissolved and applied as a liquid. Should not come in contact with plants. 3 lbs., $35 \mathrm{c}$; 5 lbs., $55 \mathrm{c} ; 10$ lbs., $\$ 1.00$.

NIGHT SOIL-A natural product of decayed vegetable and organic matter containing plant food properties of special value in the flower garden. $51 \mathrm{bs}$., 20c; $10 \mathrm{lbs}$., $35 \mathrm{c} ; 25$ lbs., 60c; 100 lbs., $\$ 1.75$.

HUMUS-A highly fertile earth. For potting soil use one part HUMUS, one part Night Soil and an equal quantity of ordinary earth. 5 lbs., $20 \mathrm{c} ; 10 \mathrm{lbs}$., $35 \mathrm{c}$; 25 lbs., 60c; 100 lbs., $\$ 1.75$.

MURIATE OF POTASH-5 lbs., 30c; 10 lbs., 50c.

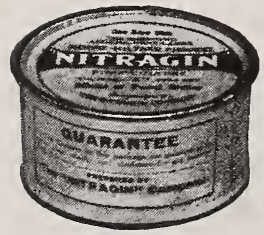

NITRAGIN-A bacteria culture for legumes. Garden size for peas, beans, lima beans and sweet peas. Directions with each package. Garden size, 20c.

We can also supply inoculator for clover, alfalfa and soy beans in the following sizes:

$1 / 2$ bushel, $60 \mathrm{c} ; 1$ bushel, $\$ 1.00 ; 5$ bushels, $\$ 4.50$.

In repotting plants, do not use earthen pots that are too large; it is better to repot several times during growth, using pots of proper size. 


\section{IN $3 E C T$ DESTROYERS AND FUNGICIDES}

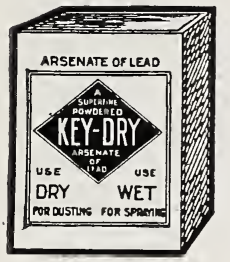

ARSENATE OF LEAD (Dry)-Efficient against leaf-eating insects. May be used as a dust or applied as a wet spray with water. Adheres to the foliage, is not easily washed off by rain and will not burn. $1 / 2$ lb., $30 \mathrm{c} ; 1$ lb., 50c; 4 lbs., $\$ 1.50$.

BLACK LEAF 40-A highly concentrated solution of Nicotine Sulphate, highly recommended as a spray for soft-bodied sucking insects. 1 oz., bottle, $35 \mathrm{c}$; $1 / 2$ lb., $\$ 1.25 ; 2$ lbs., $\$ 3.75$.

BLACK LEAF F2 - A highly effective nicotine dust used to combat striped cucumber beetle and other insects on melon vines, squash and other plants. 5 lbs., $\$ 1.25$.
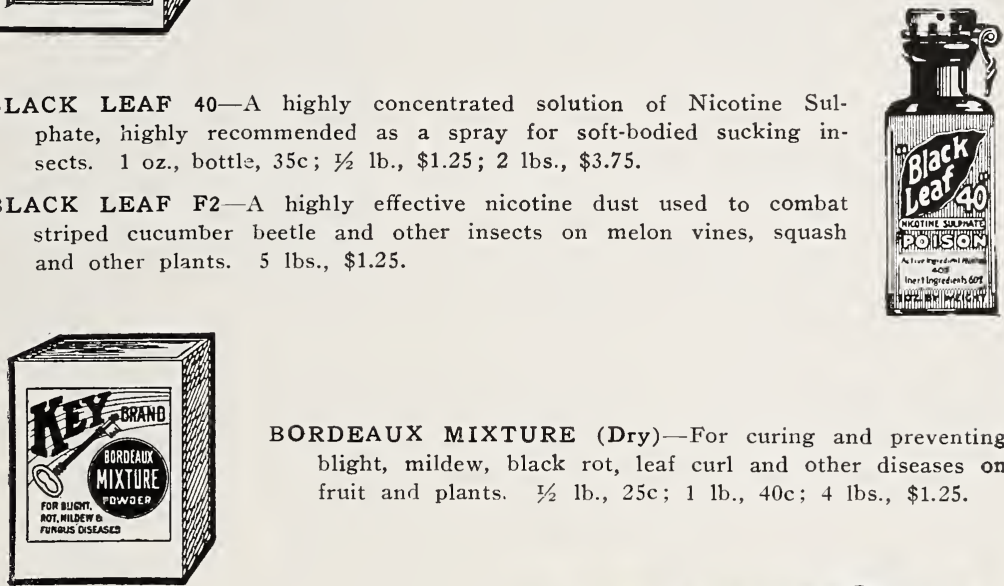

BORDEAUX MIXTURE (Dry)-For curing and preventing blight, mildew, black rot, leaf curl and other diseases on fruit and plants. I/2 lb., 25c; 1 lb., 40c; 4 lbs., $\$ 1.25$.

CARBOLA-A white paint and disinfectant combined, in powder form, that is ready to use as soon as mixed with water, and is applied with brush or spray pump. Used in cellars, dairies, creameries, rabbit hutches, garages, warehouses, poultry houses, factories, outbuildings, hog pens and dog kennels. Trial size, $40 \mathrm{c} ; 10 \mathrm{lbs}$., $\$ 1.30$.

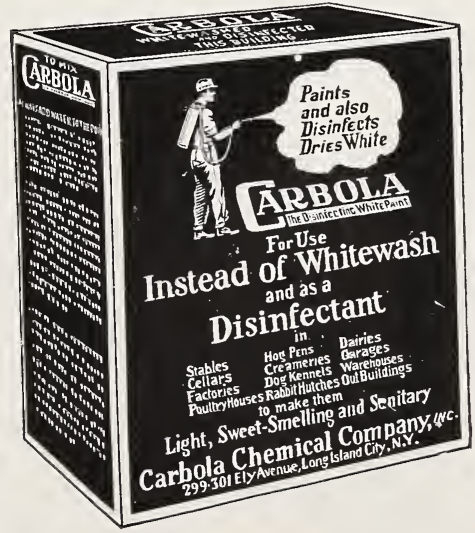

CUT WORM KILLER-For use as a poisonous bait against cut worms and slugs by placing around plants subject to attack. Full directions on package. $1 \mathrm{lb} ., 40 \mathrm{c}$.

DRY LIME SULPHUR-For dormant spraying of fruit or shade trees and shrubbery against scale. Also for peach leaf curl and brown rot of peaches. One pound makes 3 to 5 gallons. 1 lb., $35 \mathrm{c} ; 5$ lbs., $\$ 1.20 ; 10$ lbs.. $\$ 2.00$. 
FISH OIL SOAP-Combined with water, makes an effective spray for the destruction of plant lice, aphis and flea-beetles, also insects affecting the bark. $1 \mathrm{lb}, 25 \mathrm{c}$.

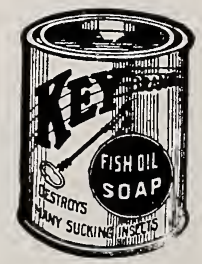

GRAFTING WAX-Convenient when grafting, trimming and pruning. 1 lb., $40 \mathrm{c}$.

HELLEBORE POWDER-A non-poisonous insecticide which may be used on fruits and vegetables when nearly ripe. $1 / 21 \mathrm{~b} ., 35 \mathrm{c} ; 1 \mathrm{lb},{ }^{2} 60 \mathrm{c}$.

MELROSINE-A concentrated liquid insecticide for use against plant lice, leaf hoppers, thrips, red spiders and as far as we know is the only effective remedy for rose chafers, rose bettles and rose curculio. Trial size can, $50 \mathrm{c}$; pint, $\$ 1.00$; quart, $\$ 1.75$.

PARA-DICHLORO-BENZENE-For peach tree borer. When placed. around the base of a peach tree, will generate a gas that will kill the borers in that tree. Use about one ounce per tree. Full directions on container. $1 \mathrm{lb}$., $60 \mathrm{c}$.

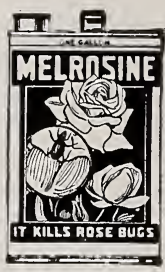

PARIS GREEN-A poisonous insecticide used against leaf-eating worms and beetles. 1 lb., 50 c; 5 lbs., $\$ 2.00 ; 14$ lbs., $\$ 5.25$.

PYROX-Easily mixed with water. Kills leaf-eating insects and controls fungus diseases. 1 lb., 50c; 5 lbs., $\$ 1.75$.

SCALECIDE-A dormant spray for fruit trees. One gallon makes 16 gallons of spray. Needs no spreader. Takes the place of dry lime sulphur. 1 qt., $60 \mathrm{c} ; 1$ gal., $\$ 1.40$.
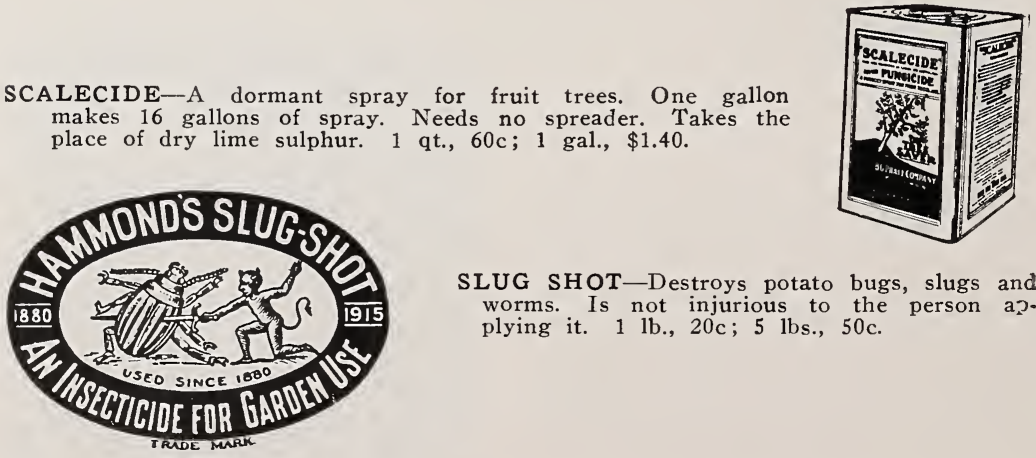

SLUG SHOT-Destroys potato bugs, slugs and worms. Is not injurious to the person a?. plying it. 1 lb., 20c; 5 lbs., 50c.

TOBACCO DUST-Used for fumigating and for dusting plants affected with aphis. 5 lbs., $30 \mathrm{c}$; 10 lbs., $50 \mathrm{c} ; 100$ lbs., $\$ 4.00$.

\section{SPRAYERS AND DUSTERS}

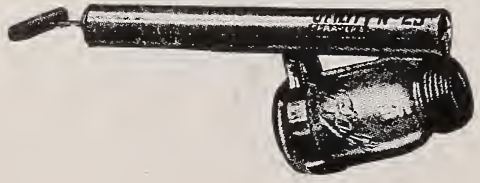

GLASS JAR SPRAYER-Adapted for small gardens, plants, flowers, disinfecting, etc. Pump cylinders are $13 / 4 \times 141 / 2$ inches in size. Packed separately in boxes which prevent breakage. Each $\$ 1.00$.

THREE-QUART GALVANIZED SPRAYER. Each $\$ 1.50$. 


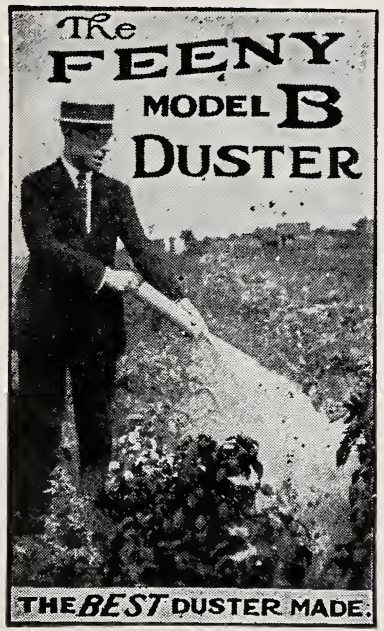

FEENY DUSTER, Model B-For applying insecticides and fungicides in dust form. Unsurpassed for the use of Arsenate of Lead, Paris Green and Tobacco dust on flowers, melons or tobacco. Each $\$ 1.00$.

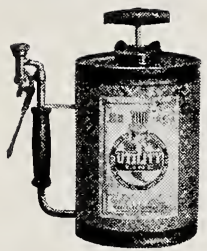

ONE GALLON SPRAYER-Most convenient size compressed air sprayer. Especially adapted to greenhouses, small gardens, disinfecting, etc. Pump cylinder of heavy brass. Filling cap of ample size and easy to remove without a wrench. Self-closing type nozzle of brass, provided with strainer. Galvanized iron tank. Each \$3.50.

ONE GALLON SPRAYER with brass tank, each $\$ 5.00$.

TIN SPRAYER-1 qt. capacity. Each $\$ 0.50$.

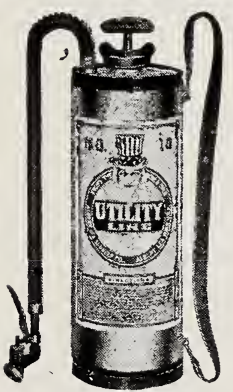

KNAPSACK SPRAYER-Compressed Air Type. This type of sprayer is the most popular for all general work requirir. a sprayer. It is adapted for spraying, whitewashing, disinfecting, for the application of glue sizing, etc. The No. 10 tank is made of galvanized steel, the No. 15 of brass. Size, $71 / 4$ by 20 inches; capacity, $31 / 2$ gallons.

No. 10-Galvanized Tank, $\$ 6.00$. No. 15 -Brass Tank, $\$ 8.00$

PARAGON SPRAYER No. 1-Capacity 6 gallons. Just the size for a small orchard or where there is a good deal of whitewashing to be done. Equipped with continuous agitator and non-clog feature, 5 feet of pipe and 5 feet spray hose. Heavy galvanized tank. Each $\$ 17.50$.

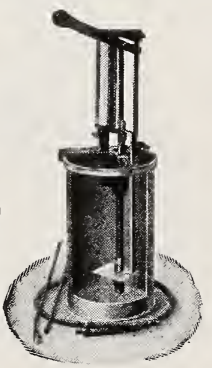


No. 40 PORTABLE-Designed for general spraying, painting, whitewashing and disinfecting. Equipped with 18 gallon tank, heavily re-inforced. Pressure of 150 to 200 pounds can easily be maintained. Discharge equipment consists of spray rods, 10 feet of hose and automatic nozzle. Price complete, $\$ 25.00$.

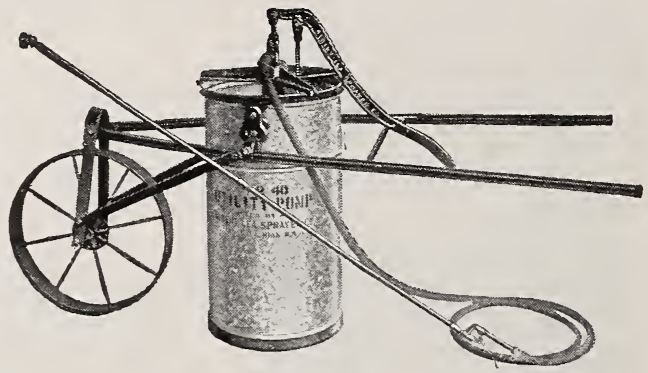

BUCKET SPRAY PUMP-The ball type valves are of brass. Will handle any liquid sprays, whitewash and cold water paint. Price complete, $\$ 3.50$.

DUSTER No. 170-For the application of Dry Arsenate, Paris Green, Slug Shot. Iron and brass machine cut gears. Hopper holds about a quart, complete equipment weighs 6 pounds. Equipped with two-way connection and all joints necessary for dusting two rows at a time. Fan $31 / 2 \times 61 / 2$. Equipped with adjustable shoulder strap and feed valve indicator. Each complete, $\$ 9.00$.
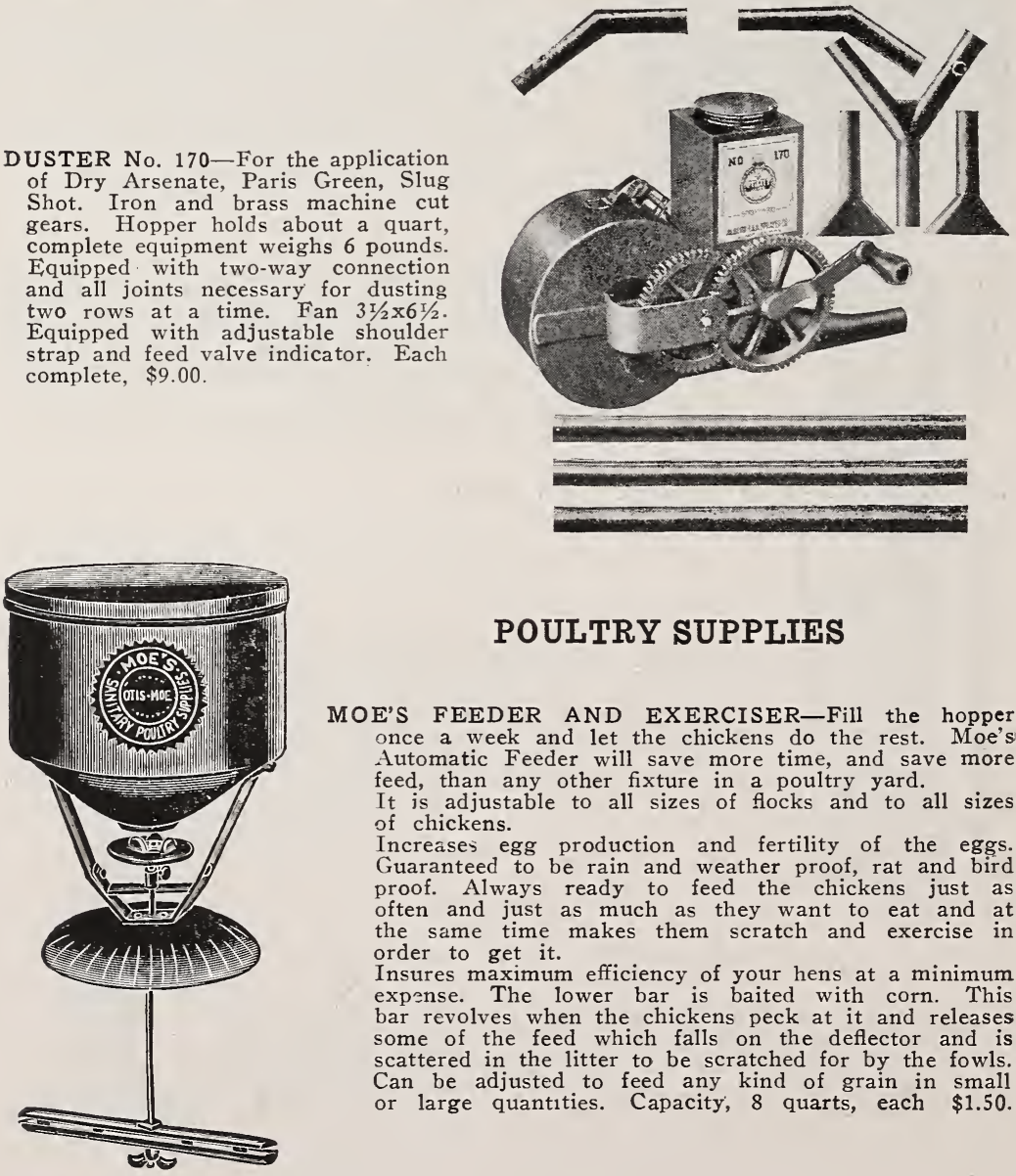

\section{POULTRY SUPPLIES}

MOE'S FEEDER AND EXERCISER-Fill the hopper once a week and let the chickens do the rest. Moe's Automatic Feeder will save more time, and save more feed, than any other fixture in a poultry yard.

It is adjustable to all sizes of flocks and to all sizes of chickens.

Increases egg production and fertility of the eggs. Guaranteed to be rain and weather proof, rat and bird proof. Always ready to feed the chickens just as often and just as much as they want to eat and at the same time makes them scratch and exercise in order to get it.

Insures maximum efficiency of your hens at a minimum exponse. The lower bar is baited with corn. This bar revolves when the chickens peck at it and releases some of the feed which falls on the deflector and is scattered in the litter to be scratched for by the fowls. Can be adjusted to feed any kind of grain in small or large quantities. Capacity, 8 quarts, each $\$ 1.50$. 


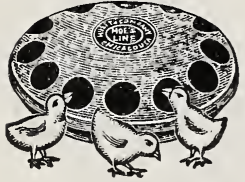

STAR FOUNTAIN AND FEEDER-Made of a single piece of heavy metal. No solder, no seams, no loose parts. Suitable for feed as well as water. Little chicks can not drown. Fits any Mason jar in 1 pint, 1 quart and 2 quart sizes.

No. 32-(Glass jar not included). Each $10 \mathrm{c}$.

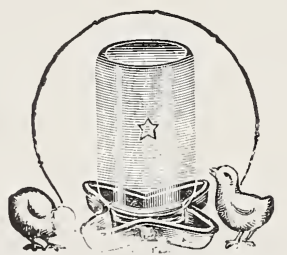

SINGLE FEEDING TROUGHS-For chicks and growing stock. Accurately stamped with dies. No rough edges and can be hung on the wall. Sliding top. Length, 18 in., 13 holes, each $40 \mathrm{c}$.

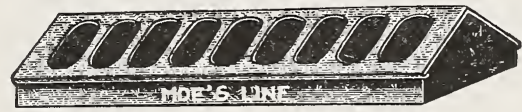

ECLIPSE FEEDING TROUGHS-For chicks and growing stock. Accurate stampings. No seams, rivets or solder. Sliding top easy to fill and keep clean. No. 27-Length, 10 in., each $25 \mathrm{c}$. No. 28-L,ength, 20 in., each $40 \mathrm{c}$.

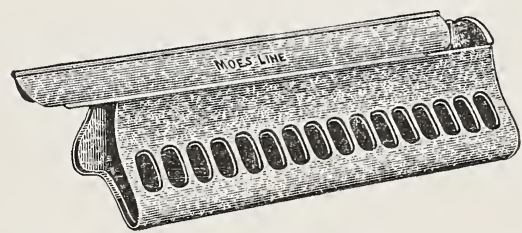

GRIT BOX No. 9-Has three compartments. Height, 13 in. Width, $81 / 2$ in. Packed 6 in a box. Shipping weight, (6) 15 lbs. Each 90c.

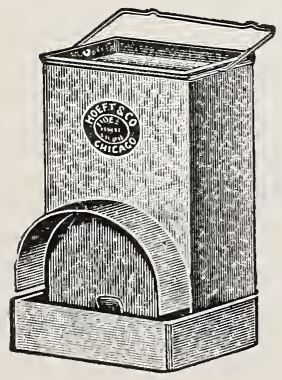

No. 36 DRY MASH HOPPER-Rat, mouse and weather proof. Capacity, 14 quarts. Each $\$ 2.00$.

DROP BOTTOM FOUNTAIN-Drop bottom, easy to fill and to clean. Has wire handle and may be hung on the wall out of the litter and dirt.

No. 41-Capacity 1 gallon. Each $\$ 1.15$. 
CHINA NEST EGGS-Made of white porcelain, natural in appearance, and uniform in size. Will not easily break. They induce the hen to lay where she should-in the nests provided for her. Per dozen $35 \mathrm{c}$.
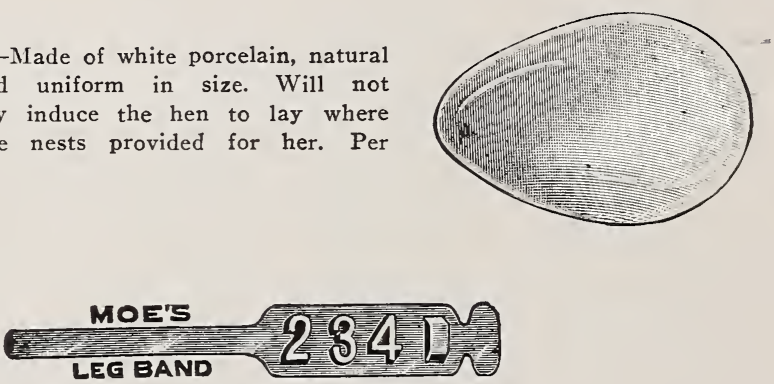

ADJUSTABLE ALUMINUM LEG BANDS-Made of sheet aluminum, with large raised numbers, easy to read from a distance. Adjustable for any size fowl. Accurately made and quickly applied. Packed in paper cartons of 12, 25, 50 and 100 each. Numbered from one up. 25 bands, 25c; 50 bands, 45c; 100 bands, 75c. When using liquid manure and other fertilizers in liquid form, do not allow the material to come in contact with foliage.

\title{
POULTRY REMEDIES
}

PRATT'S POULTRY REGULATOR-Small size, 25c; 4 lbs., 50c.

LEE'S EGG MAKER AND CHICK GROWER-2 lbs., 40c; 5 lbs., 90c.

LEE'S LIQUID LICE KILLER-1 quart, 60c; $1 / 2$ gal., $90 \mathrm{c}$.

LEE'S GERMOZONE-4 oz., 40c; 12 oz., 75c.

LEE'S WHITE DIARRHOEA REMEDY-Each 50c.

PRATT'S GAPE COMPOUND-9 oz., pkg., $25 \mathrm{c}$.

PRATT'S POULTRY DISINFECTANT-1 quart, 50c.

PRATT'S SPECIAL COMPOUND-3r $/ 2$ oz., $25 \mathrm{c}$.

PRATT'S WHITE DIARRHOEA TABLETS-25c.

PRATT'S HEAD LICE OINTMENT-30c.

PRATT'S ROUP TABLETS-25c.

LEE'S GERMOZONE TABLETS-(75), $65 \mathrm{c}$.

SOREHEAD CHICKEN-POX REMEDY-30c.

PRATT'S LOUSE POWDER-1 1b., $25 \mathrm{c}$.

PRATT'S LOUSE POWDER-21/2 lbs., $50 \mathrm{c}$.

PRATT'S FLY CHASER-1/2 gal., 90c.

PRATT'S FLY CHASER-1 gal., $\$ 1.30$.

\section{GET OUR PRICES ON CHICKEN FEEDS}

\author{
BUTTERMILK CHICK STARTER \\ CHICK MASH \\ CHICK SCRATCH FEED \\ GROWING MASH \\ LAYING MASH \\ HEN SCRATCH FEED
}




\section{POWELL'S LAWN GRASSES}

MAKING A NEW LAWN-Much care should be taken in the preparation of the soil surrounding the home as the beauty of the lawn for many years will depend. largely upon the nature of the soil from which the grass draws its nourishment. Top-soil should be removed before grading and replaced as a top-dressing before sowing seed. A liberal application of well rotted compost with bone meal or WIZARD SHEEP MANURE will furnish the proper plant food. Blue Grass seed should not be sown alone as it is very slow in making a "stand", but should be mixed with some other grass of quicker growth to shield the young Blue Grass from summer sun and wintery frost.

SOWING THE SEED-This should be done on a still dry day, first raking the surface down so as to form a perfect seed-bed. Divide the seed to be sown into two equal parts. Scatter the seed as evenly as possible on the lawn, walking north and south in the distribution of half the seed, then sow the remaining half by walking east and west-thus "checking" to assure even distribution. After sowing the seed rake lightly or firm the seed with a lawn roller.

RENOVATING AN OLD LAWN-Apply WIZARD sheep manure at the rate of 6 or 8 pounds to each 100 square feet. Scatter some grass seed over thin places, raking the ground before and after sowing. Where the soil is sandy or heavy clay, a top dressing of humus will be found beneficial as it furnishes a moistureretaining mulch and is high in nitrogen, an essential grass food. If the soil is damp and sour, hydrated lime or ground limestone will correct the acidity and promote plant growth.

ABOUT WATERING-Remember that a good soaking once a week is vetter than sprinkling every day. Teach the roots to go deeply into the soil. Too much watering makes the soil sour.

CUTTING THE GRASS-This should be done on a cloudy day or late in the afternoon-never on a hot, surny day. This should be borne in mind especially in the treatment of young grass.

1 lb. $\quad 5$ lbs. $\quad 10$ lbs.

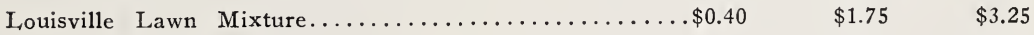

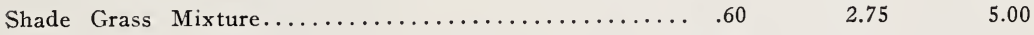

White Dutch Clover........................ $80 \quad 3.75$

Kentucky Blue Grass....................... .45 $2.00 \quad 3.50$

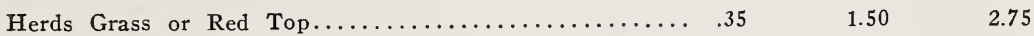

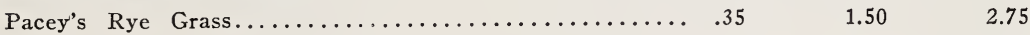

As Kentucky Blue Grass is very slow in making a sod, we recommend sowing new lawns with a mixture of Kentucky Blue Grass and other grasses which will produce a lawn quickly. WIZARD SHEEP MANURE is the best fertilizer. 


\section{INDEX}

Page numbers prefixed with S, Seeds; P, Plants.

A

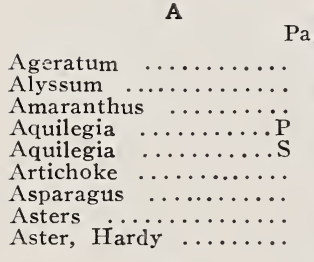

B

Ralsam ........... 22

Balloon Vine ........ 22

Beans $. \ldots \ldots \ldots \ldots .2-4$

Beets ................ 4-5

Books ............32-33

Bulb Pans ............ 35

Brussels Sprouts ..... 5

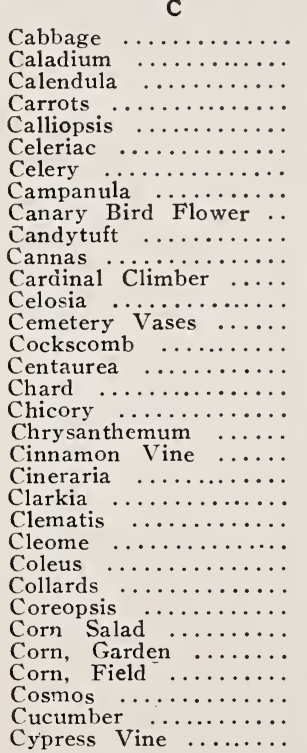

D

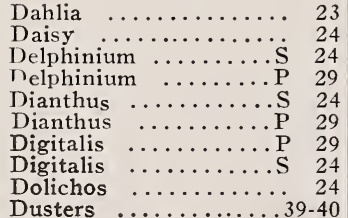

E

Egg Plant
Gaillardia

Gaillardia ............ 24

Garden Tools .......... 34

Gladioli ...........30-31

Gold Dust ........... 24

Golden Glow ........ 29

Gourds $\ldots \ldots \ldots \ldots \ldots .24$

Grass Seed ......... 43

$\begin{array}{lll}\text { Gypsophila } \ldots \ldots \ldots . & \\ \text { Gypsophila } & 24 & \\ \end{array}$

$\mathrm{H}$

Hollyhock $\ldots \ldots \ldots . .6$

Hollyhock ...........P

Humulus ........... 25

Insecticides

\section{I}

............ 10

Kochia ............ 25

Kohl Rabi ........... 10

Labeis, Woode

\section{L}

Lantana Wooden .......

Larkspur ..............

Lawn Grass ...........

Lettuce $\ldots \ldots \ldots \ldots \ldots .11$

Lobelia $\ldots \ldots \ldots \ldots \ldots \ldots, 25$

\section{$\mathbf{M}$}

Marigold $\ldots \ldots \ldots \ldots \ldots, 25$

Melon, Musk ........ 12

Melon, Water ....... 13

Mignonette $\ldots \ldots \ldots \ldots .25$

Moonflower $\ldots \ldots \ldots \ldots .25$

Morning Glory ....... 25

Mustard ............. 13

\section{$\mathrm{N}$}

Nasturtium Dwarf ....

Nasturtium Tall ......

Nicotiana ...........

Nigella .............

Okra $\ldots \ldots \ldots \ldots \ldots \ldots$
Onions $\ldots \ldots \ldots \ldots \ldots$

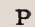

Pansy

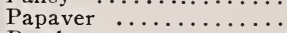

Parsley ................

Parsnip $. . . \ldots \ldots \ldots \ldots . . .6$.

14

10 Peanuts .......... Page

Peas, Garden ...........14-15

Peonies ............. 31

Pepper ............15-16

Perennial Peas ...... 26

Perennial Plants ..... 29

Perennial Flax ....... 26

Petunia ........... 26

Phlox ............ 29

Phlox .............. 26

Plant Tubs .......... 34

Pop Corn .......... 8

Poppies ............ 26

Portulaca $\ldots \ldots \ldots \ldots, 27$

Pots, earthen ...... 35

Pots, paper ..........3.34

Poultry Remedies .... 42

Poultrv Supplies ...... 40

Pumpkin ........... 16

Pyrethrum .......... 27

Pyrethrum …......P 29

\section{$\mathbf{R}$}

Radish $\ldots \ldots \ldots \ldots \ldots, 16$

Red Top .......... 43

Rhubarb Roots ..... 17

Rutabaga ............ 19

\section{$\mathrm{s}$}

Salpiglosis $\ldots \ldots \ldots \ldots, 27$

Salsify $\ldots \ldots \ldots \ldots \ldots, 17$

Salvia ................ 27

Scabiosa ............. 27

Schizanthus …....... 27

Sensitive Plant ....... 27

Shamrock, İrish ….... 27

Shasta Daisy ........ 29

Smilax ............ 27

Snapdragon $\ldots \ldots \ldots \ldots .27$

Spinach ........... 17

Sprayers ...........38-40

Squasn $\ldots \ldots \ldots \ldots \ldots 18$

Statice $\ldots \ldots \ldots \ldots \ldots \ldots \ldots \ldots .27$

Stocks $\ldots \ldots \ldots \ldots \ldots \ldots, 27$

Sunflower $\ldots \ldots \ldots \ldots \ldots .27$

Sweet Peas ........... 28

Sweet Sultan ........ 28

Sweet William .......... 27

\section{$\mathrm{T}$}

'Thunbergia $\ldots \ldots \ldots \ldots, 27$

Timothy $\ldots \ldots \ldots \ldots \ldots .21$

Tomatoes ......... 19

Tohacco $\ldots . \ldots \ldots \ldots . .20$

Tuberose $\ldots \ldots \ldots \ldots \ldots \ldots, 30$

Turnips $\ldots \ldots \ldots \ldots \ldots 19$

\begin{tabular}{c|ccc}
25 & v & \\
26 & Verbena & $\ldots \ldots \ldots \ldots$ & 27
\end{tabular}

Vinca $\ldots \ldots \ldots \ldots \ldots \ldots, 27$

\section{$\mathrm{W}$}

14 Wallflower .......... 27

Weeders $\ldots \ldots \ldots \ldots \ldots, 34.34$

Wildflower, Garden .... 28

Winter Radish ...... 17

Zinnia 


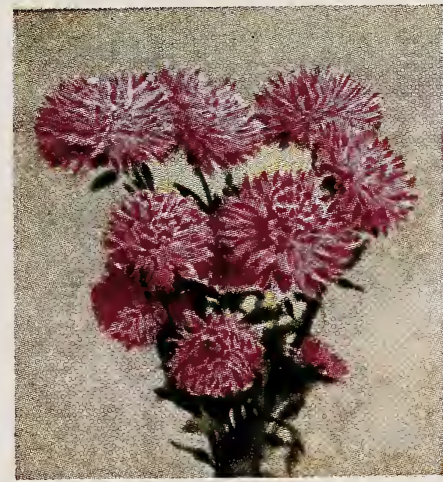

American Beauty

This is a sturdy late type with heavy stiff stems and flowers 4 to 5 inches in diameter.

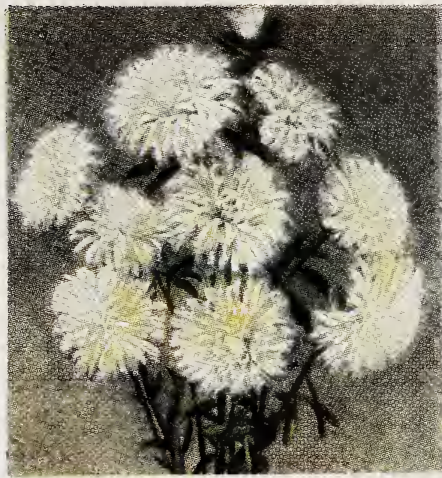

\section{Crego}

One of the most popular types. The petals of the immense flowers are gracefully curved and twisted like ostrich feathers.

\section{Brighten Your Garden with Asters}

Seed may be sown in open seedbed when the earliest trees start to leaf, or still earlier in hotbed or cold-frame. For a long period of bloom we advise planting a number of the distinct types listed below.

\begin{tabular}{clll} 
American Beauty & Giant Crego & Daybreak & \multicolumn{1}{c}{ King } \\
Purple Beauty & Shell-Pink & Blue-Bird & Crimson King \\
Pink Beauty & Azure-Blue & Lavender & Lavender King \\
Lavender Beauty. & Purple & Purity-White & Pink King \\
Beauty Rose & White & Rose & Rose King \\
White Beauty & Rose-Pink & Silver-Pink & White King
\end{tabular}

Any of the above: Pkt., 10c; 6 pkts. of your own selection, 50c.

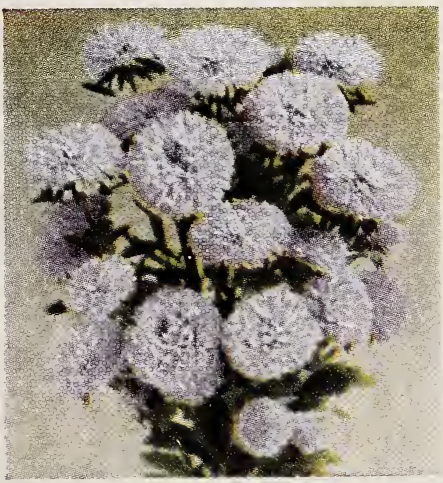

\section{Daybreak}

The well-branched plants stand erect, being 18 to 20 inches tall. The ball-shaped flowers are large. Blooms August to September.

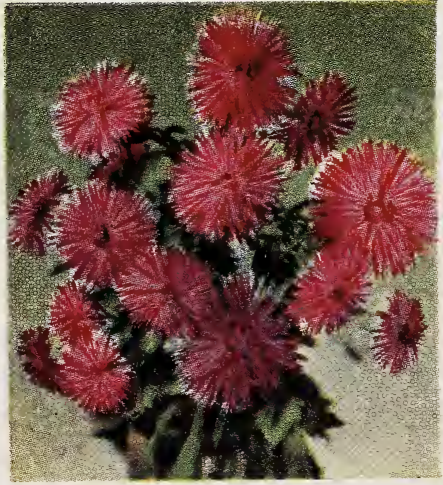

King

Coming into bloom before the late-branching Asters. Petals quilled. Set plants 12 to 15 inches apart. 


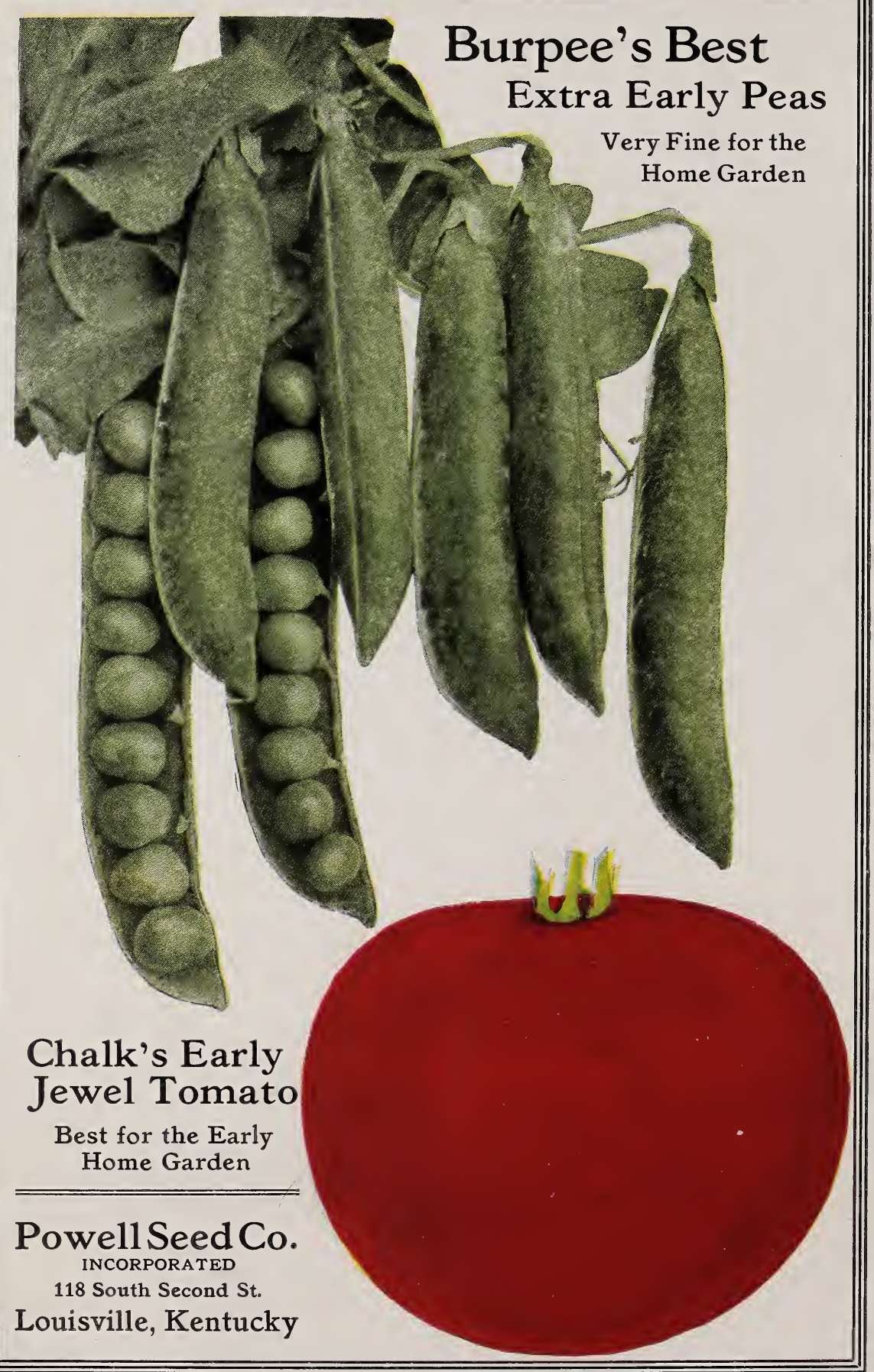

